\title{
ابن خلدون والفكر الاقتصاديّ الغربي
}

\section{كمال توفيق حطاب*}

مقدمة:

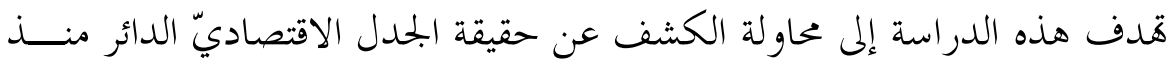
وقت طويل حول العلاقة بين الفكر الاقتصاديّ الغربيّ وفكر ابن خلدون، ومديده إنى تأثر الفكر الاقتصاديّ الغربيّ بفكر ابن خلدون بوصفه أحد الأمثلة البارزة في تاريخ الفكر

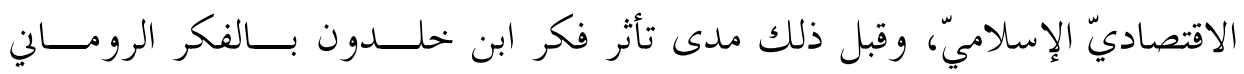

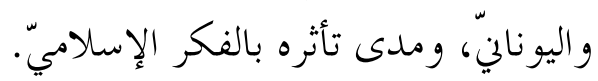

ويزعم كثير من المفكرين الاقتصاديين الغربيين أن الفكر الاقتصاديّ الغربي هــــ

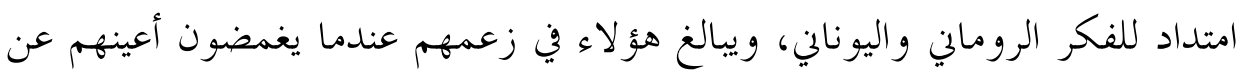

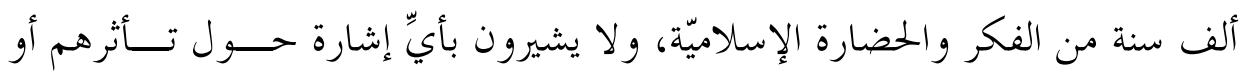
استفادهم أو حتى اطلاعهم على الفكر الاقتصاديّ الإسلاميّ. (1) وتفترض هذه الدراسة أن الكثير من المفكرين الاقتصاديين المشهورين قد أخــــوا

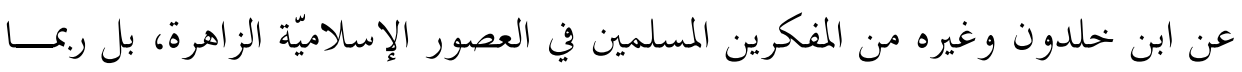

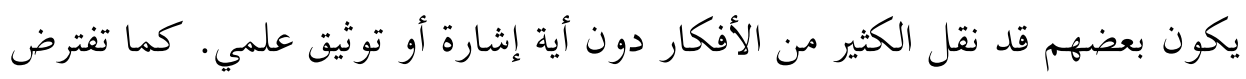
هذه الدراسة أن الفكر الاقتصاديّ الغربي مدين بالفضل للفكر الاقتصاديّ الإسلاميّ،

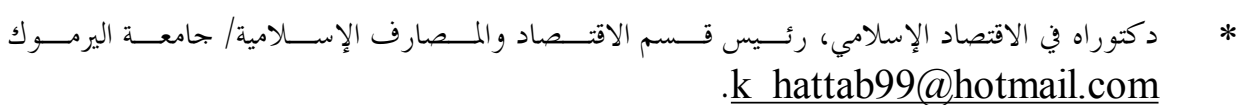

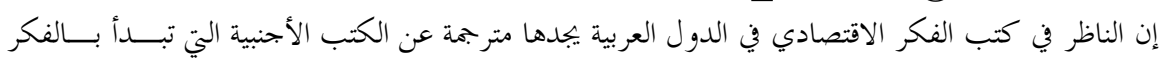

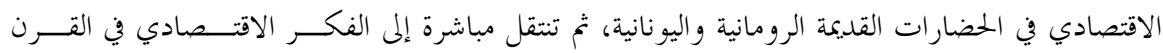

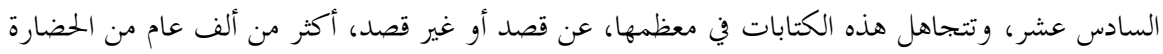

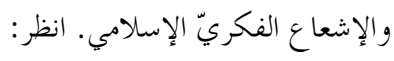

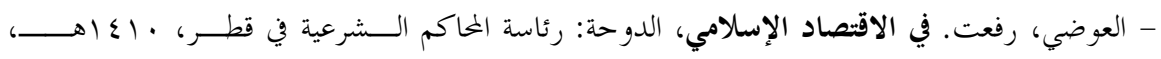


ولا سيّما ما جاء به ابن خلدون، و الغز الميّ، وابن رشد، وغيرهم. (T) وأن الإضافات التي

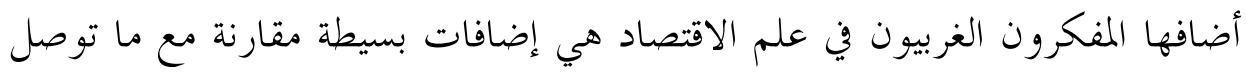

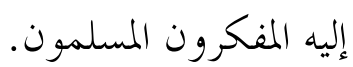

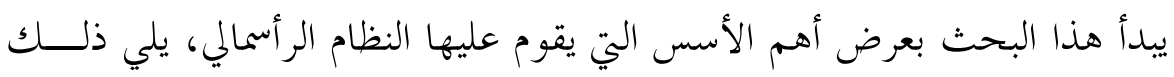

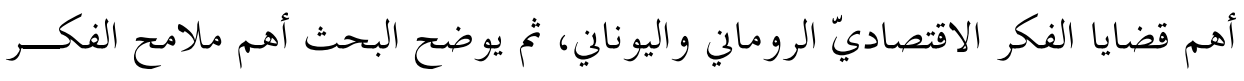

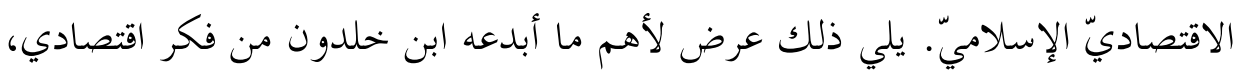

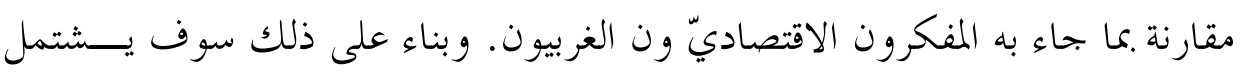

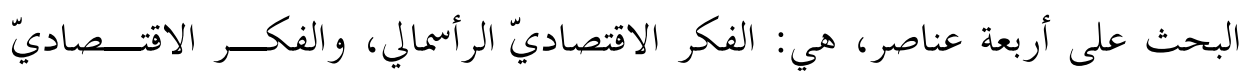

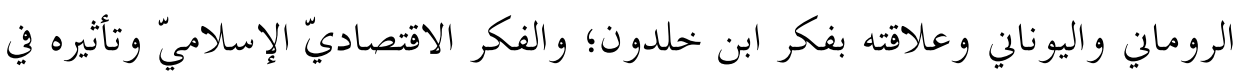
ابن خلدون؛ و الفكر الاقتصاديّ الخلدوني وتأثيره في الفكر الغني الغربي.

\section{أولا: الفكر الاقتصاديّ الرأسمالي}

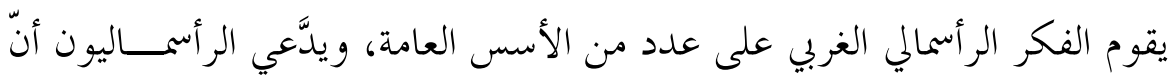

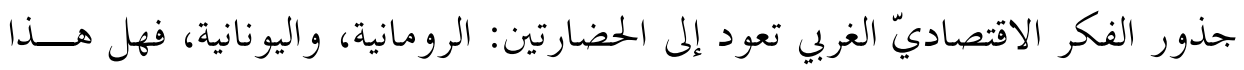

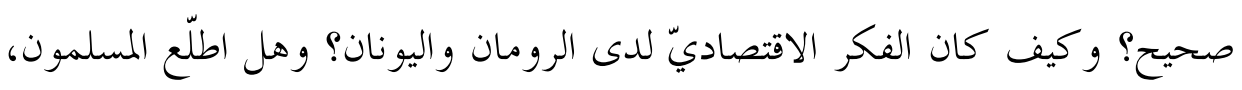

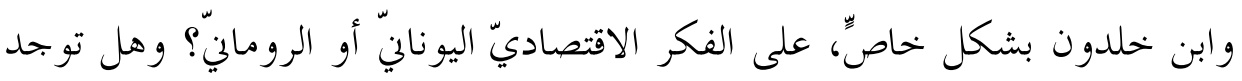
إشارات إلى ذلك؟

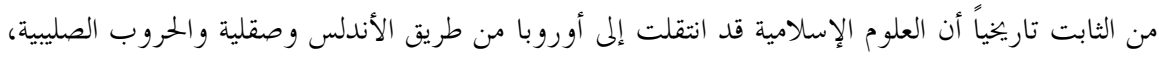

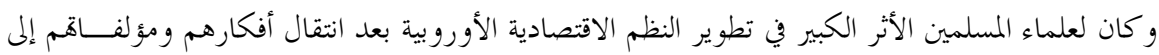

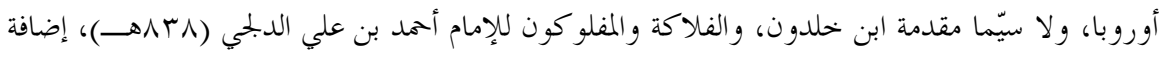

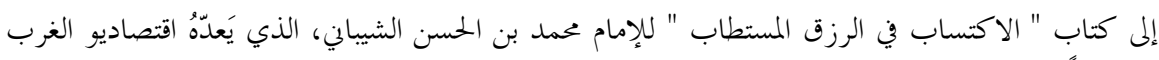

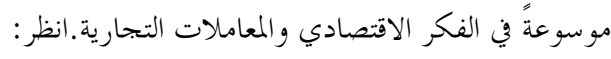

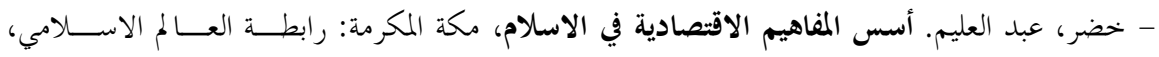


أول الأسس التي يقوم عليها الاقتصاد الرأسمالي هو الملكية الخاصة والمنفعة الذاتية

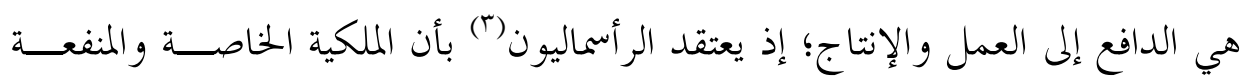

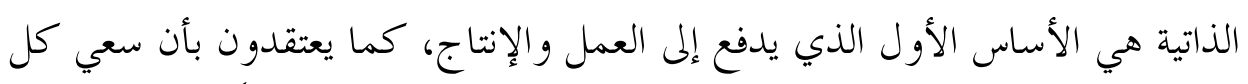

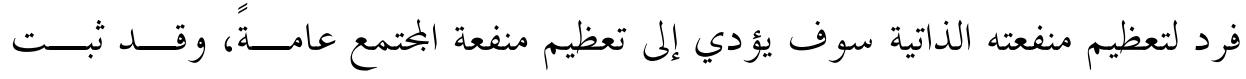

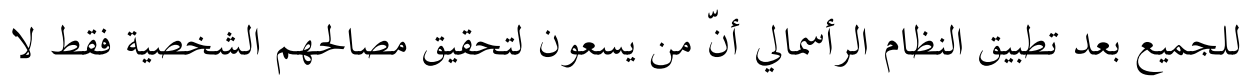

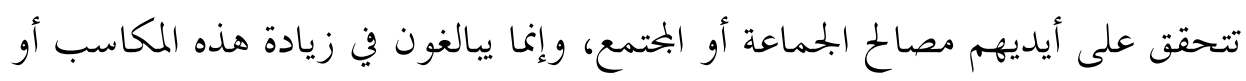

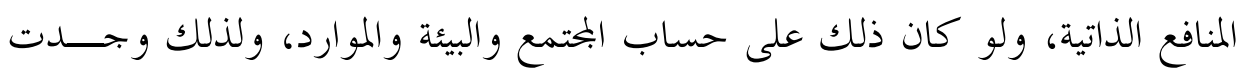

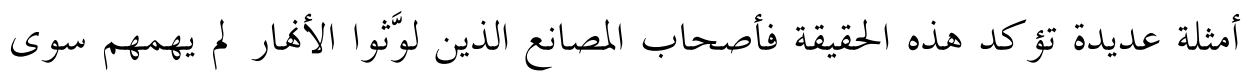

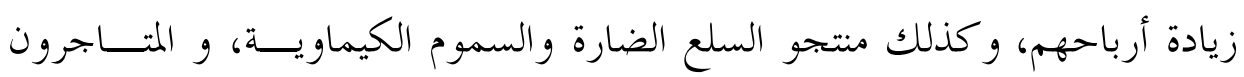

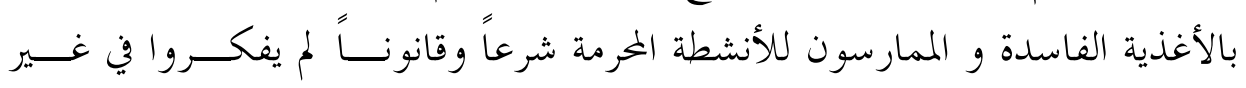

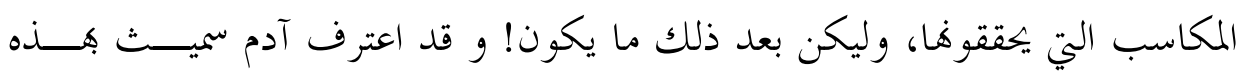

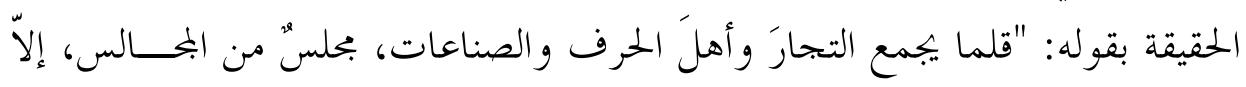

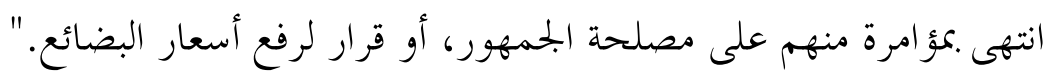
ثاني هذه الأسس هو: مبدأ الحرية الفردية المطلقة في ممارسة النشاط الاقتصاديّ،

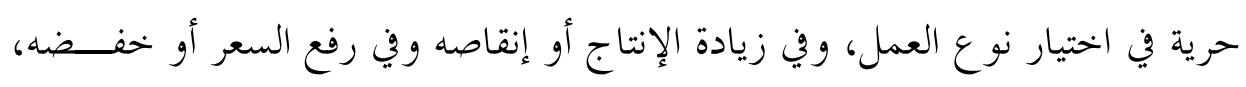

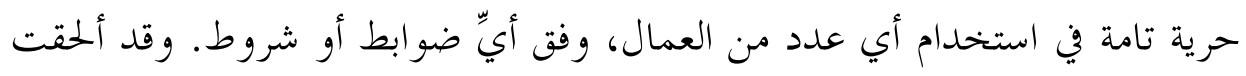

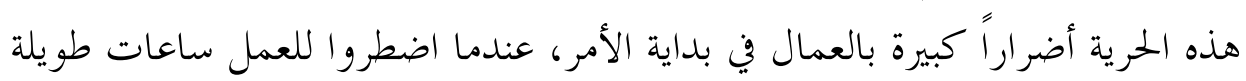

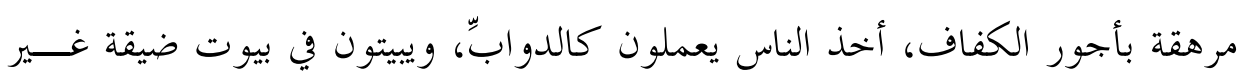

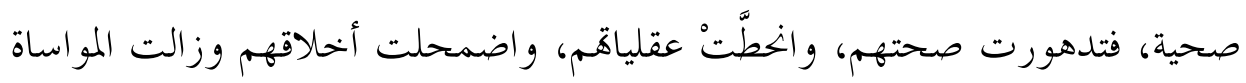

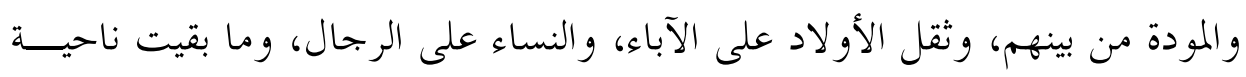

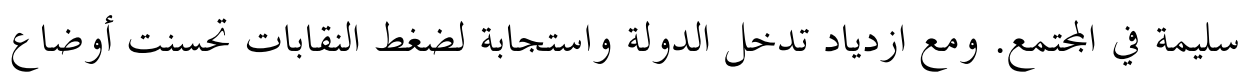

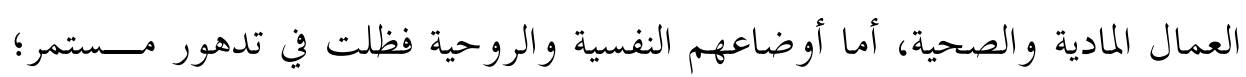

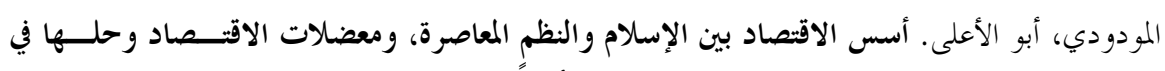

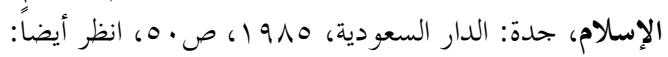
- كمال، يو سف. الإسلام والمذاهب الاقتصادية المعاصرة، المنصورة: دار الوفاء، ب1919، صهr. 
بسبب عدم وجود الوازع الايماني أثناء العمل. ومن جهة أخرى نجـــم عــن الحريسـة

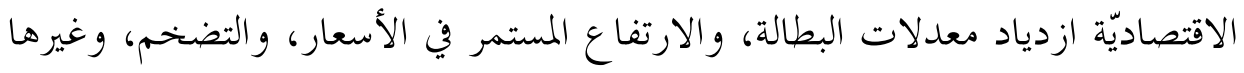

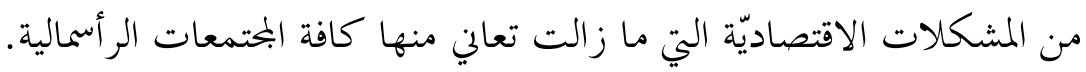

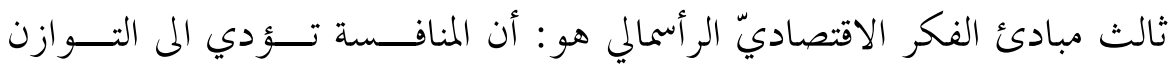

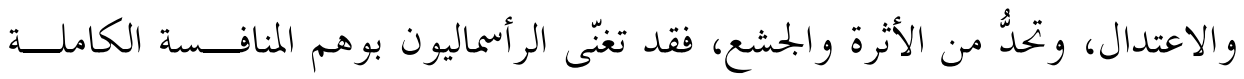

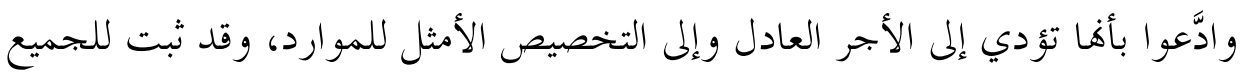

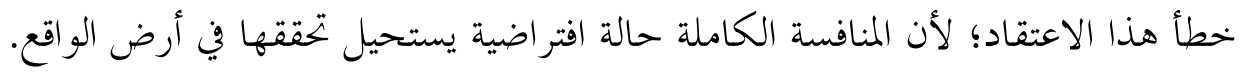

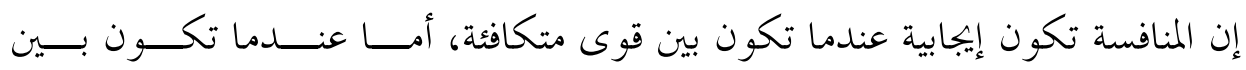

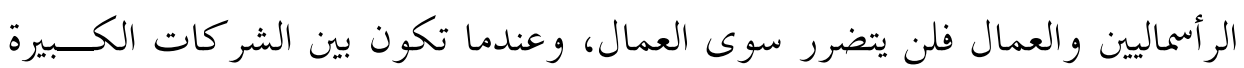
و الصغيرة فسوف تتضرر الشركات الصغيرة، وهكذا.

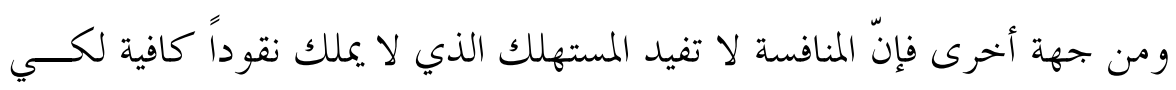

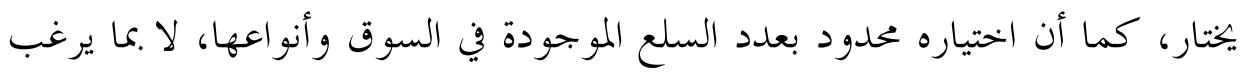

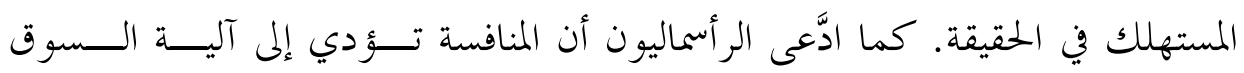

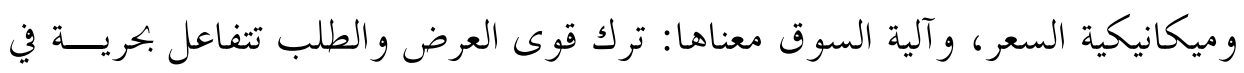

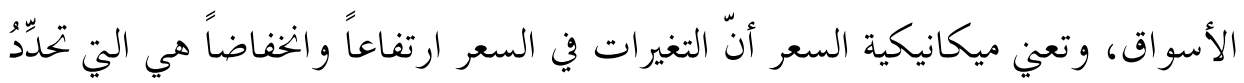
الكميات المطلوبة والمعروضة في الأسواق.

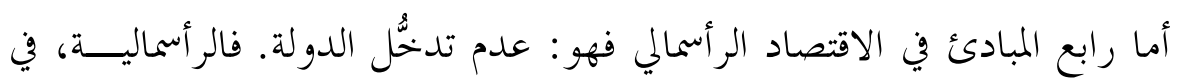

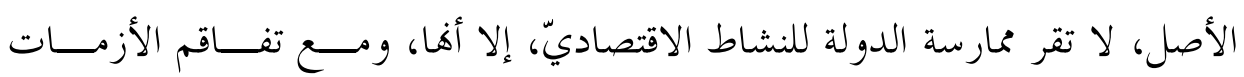

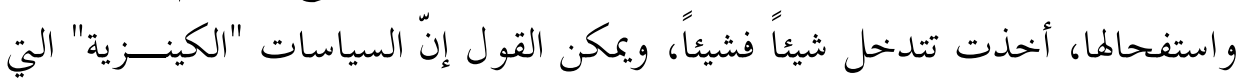

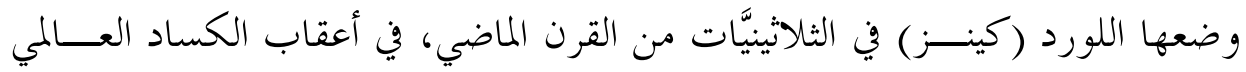

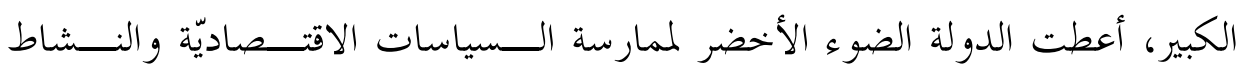

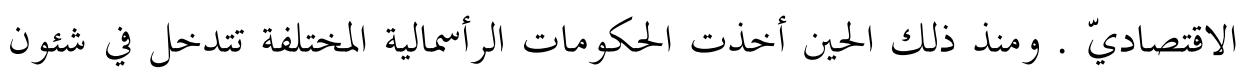

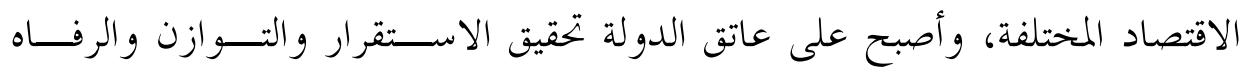

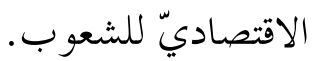




\section{ثانياً: الفكر الاقتصاديّ الروماني واليونالي وعلاقته بفكر ابن خلدون:}

تعدّ الآراء والأفكار الاقتصاديّة عند الرومان ضئيلة جداً بالمقارنة مع اليونان، ولعل

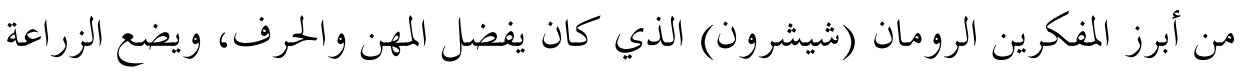

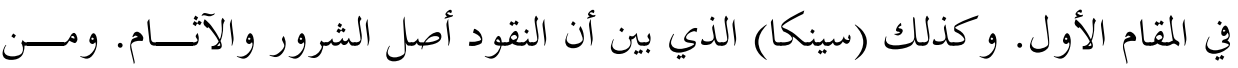

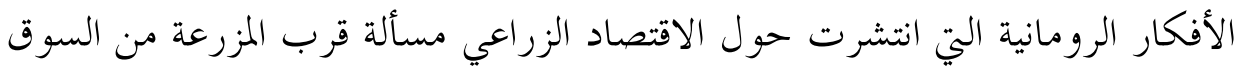

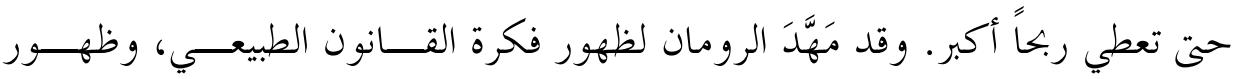

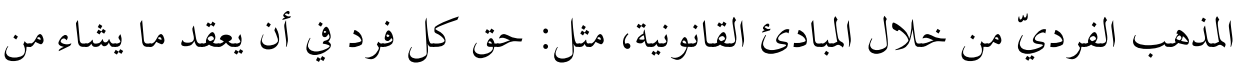

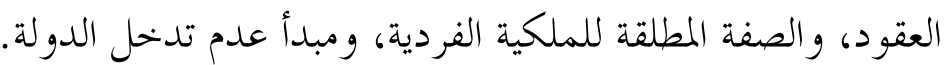

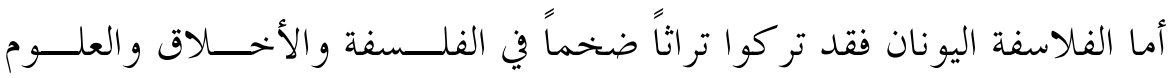

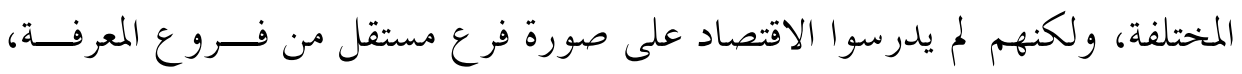

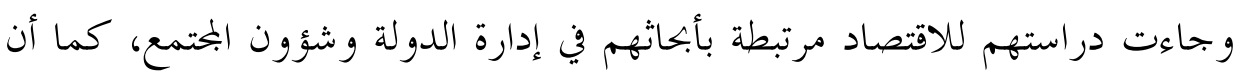

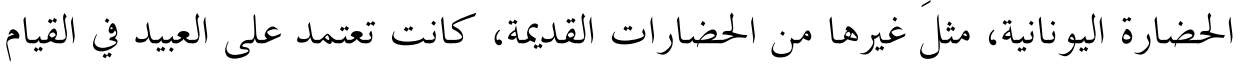

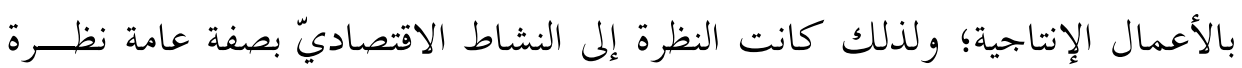
احتقار، (ई) ومن هنا كانت قلة الأبحاث في المشكلات الإنت الاقتصاديّة.

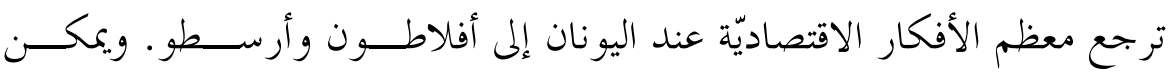

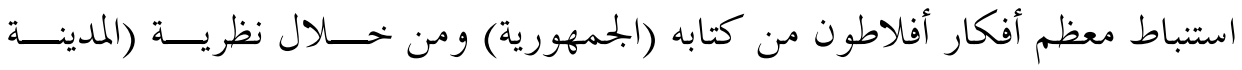

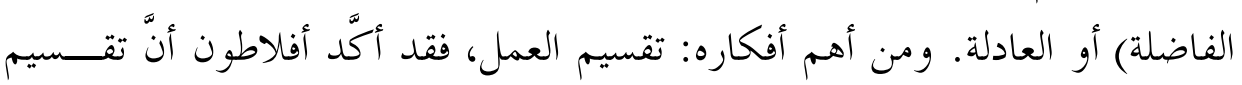

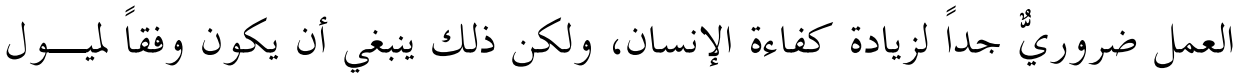

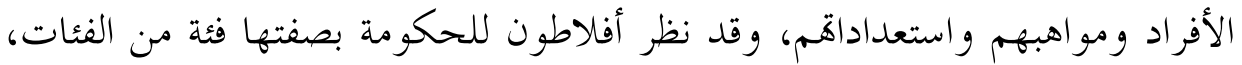

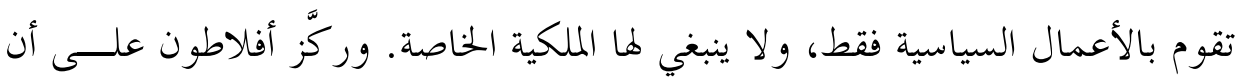

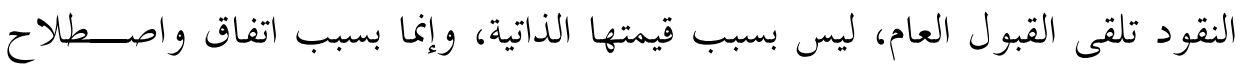

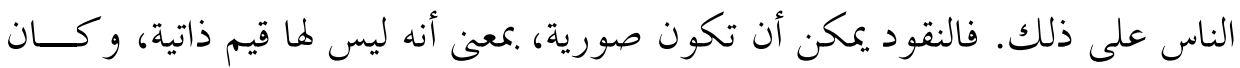

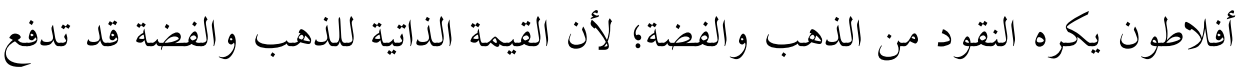




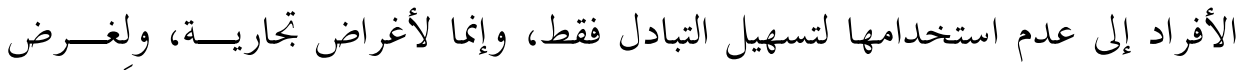

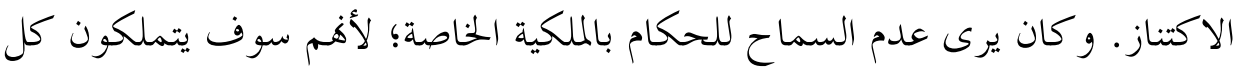
شيء، وكان يدعو إلى إنشاء نظام جماعي تكون فيه الملكية عامة.

أما أرسطو فإنه يتميز عن غيره من مفكري العصور القديمة بأنه حاول تحليل بعض

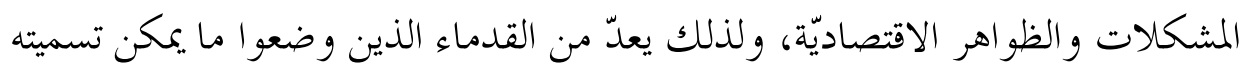

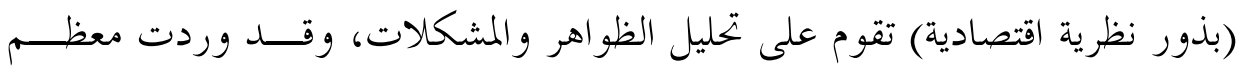

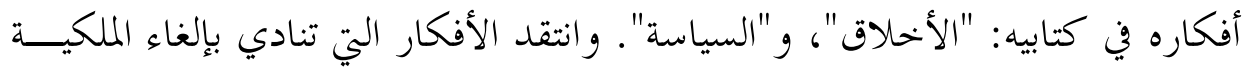

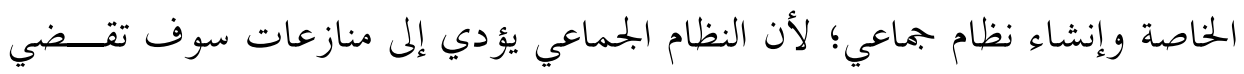

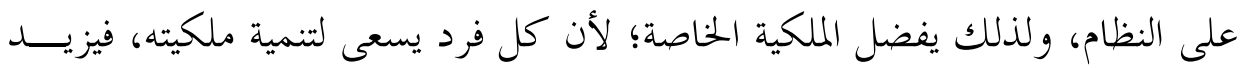

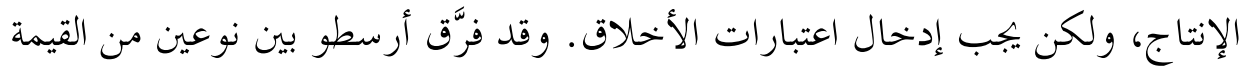
يكونان لكل سلعة من السلع، وهما: قيمة الاستعمال، وقيمة المبادلة، فالحذاء -مثلاًً

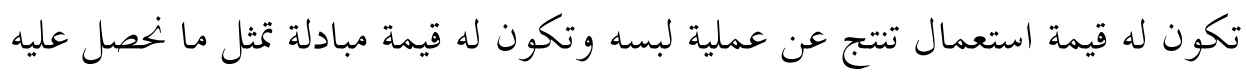

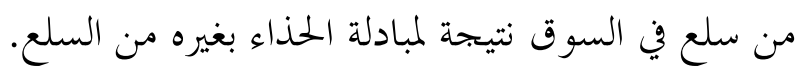

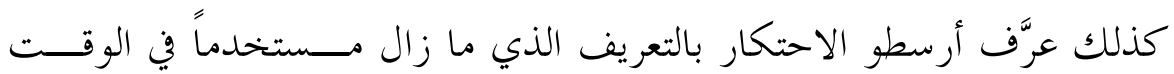

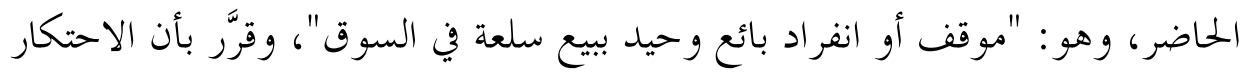

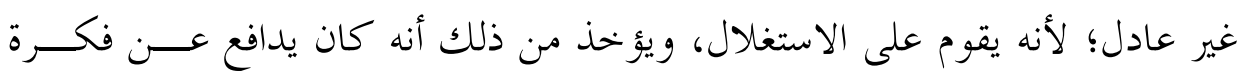

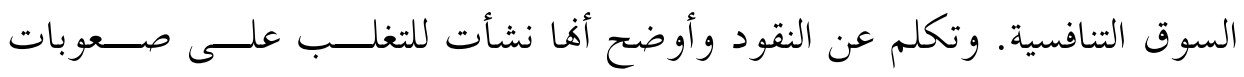

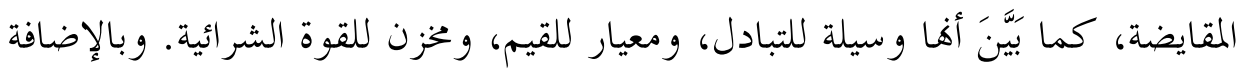

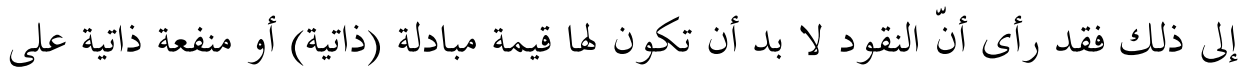

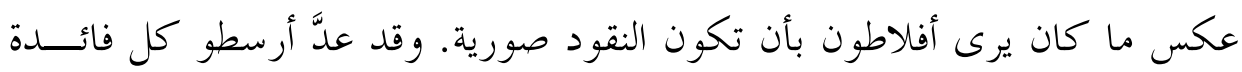

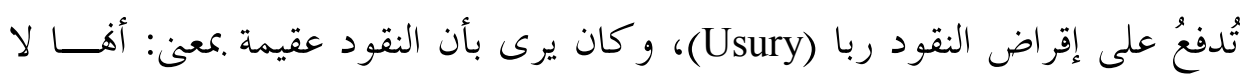
تنمو وحدها: فالنقود لا تلد النقود.

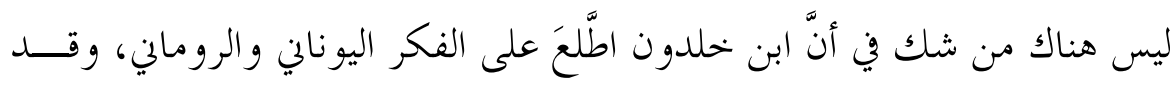

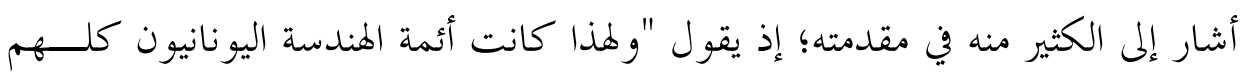


أئمة في هذه الصناعة فكان (أوقليدوس) صاحب كتاب "الأصول في الهندسة" بناراً،

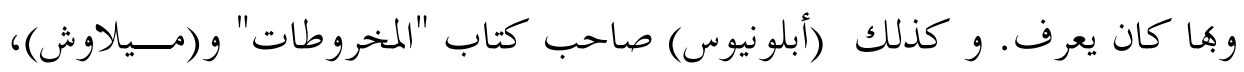

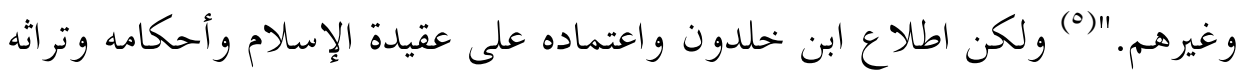
كان أكبر وأعمق، و الأمر في هذا الشأن لا يحتاج إلى دليل. لكن القراءة المتأنية لمقدمة ابن خحلدون توضح أن ابن خلدون قد اطلع على أفكار

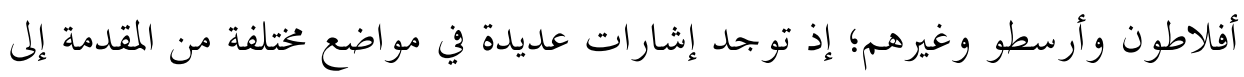
ذلك، فعلى سبيل المثال أورد في الفصل التاسع عشر عنو إناً (العلوم العقلية وأصنافها)،

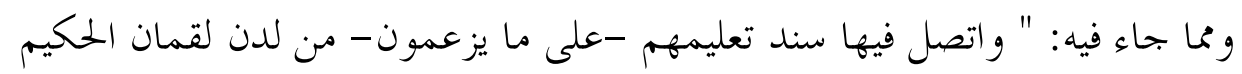

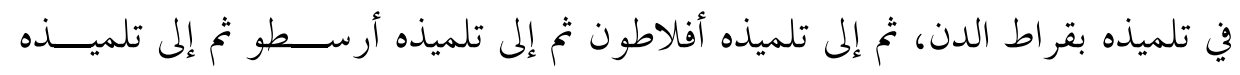

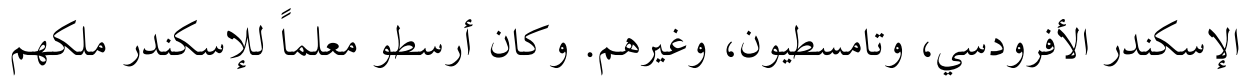

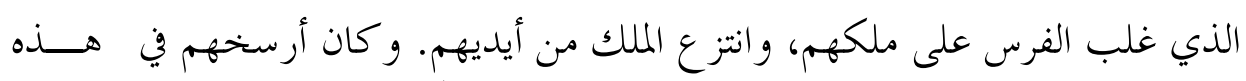

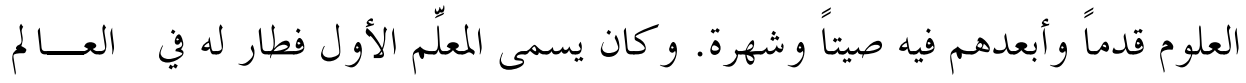

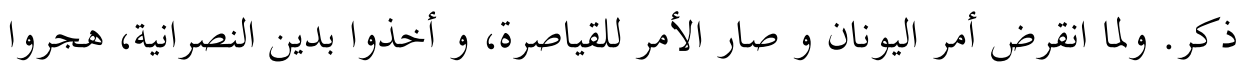

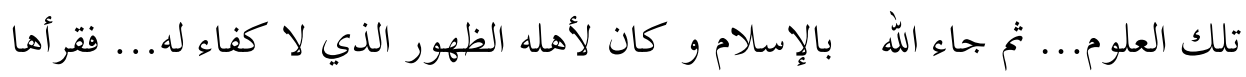

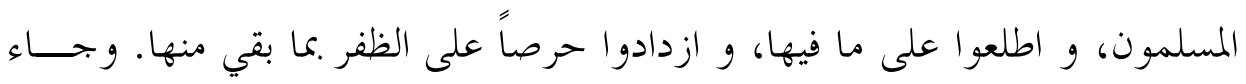

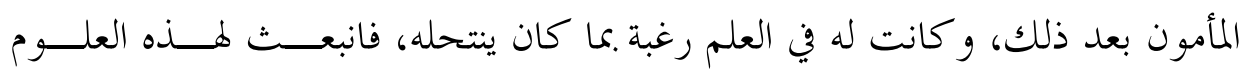

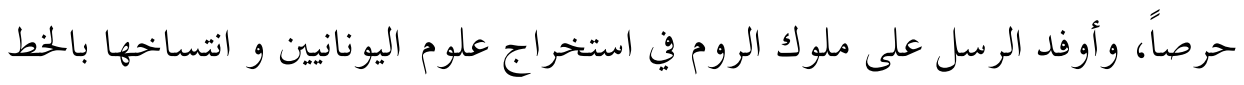

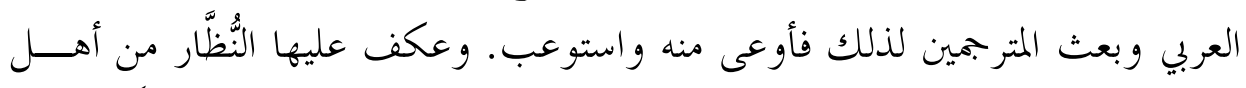

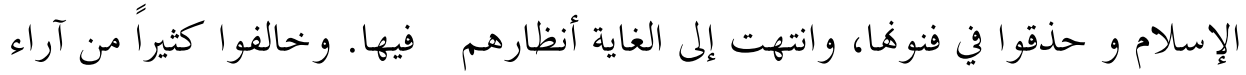

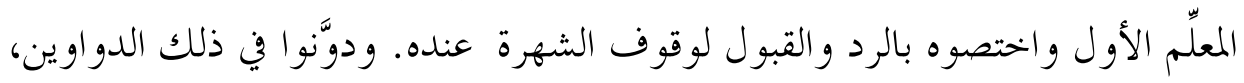

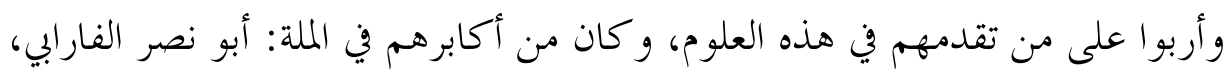

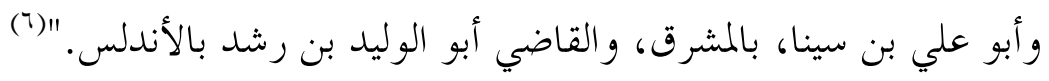


وفي موضع آخر يقول: "و كتب المعلّم الأول فيه موجودة بين أيسـدي النــاس.

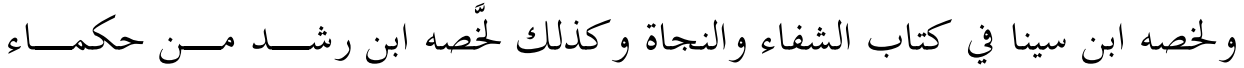

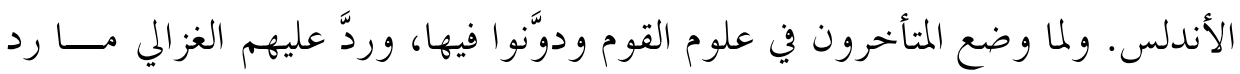

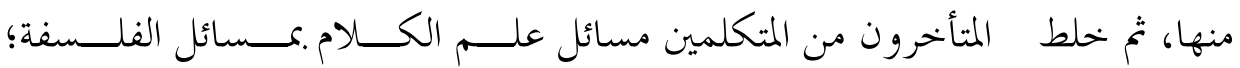

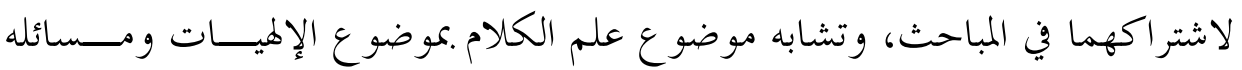

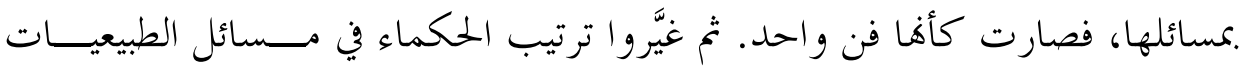

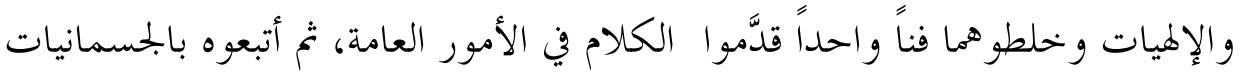

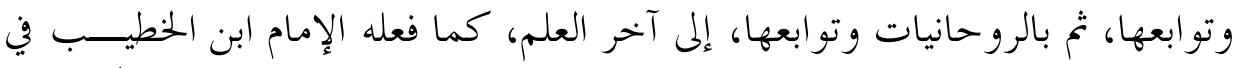

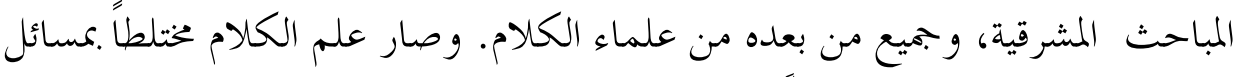

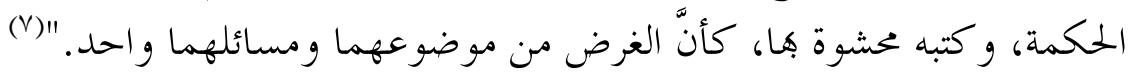
وفي موضع ثالث: "و في الكتاب المنسوب لأرسطو في السياسة المتداول بين الناس

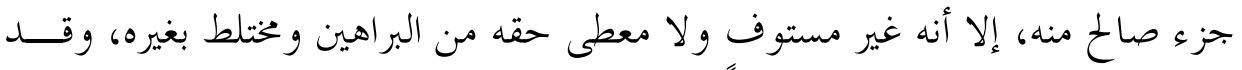

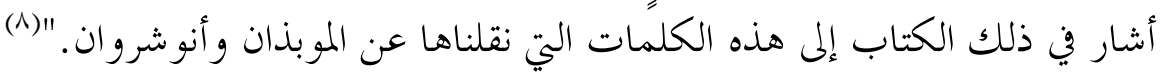

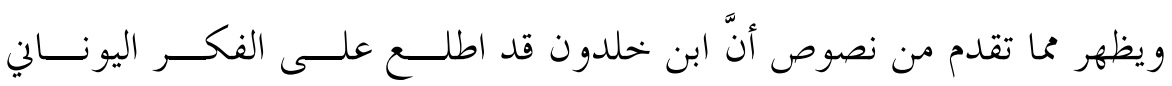

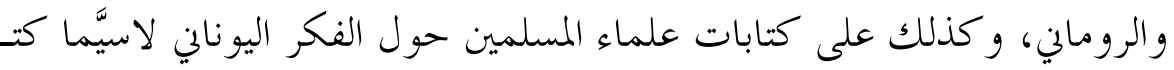

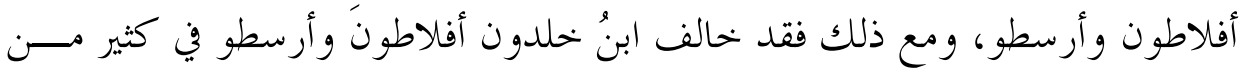

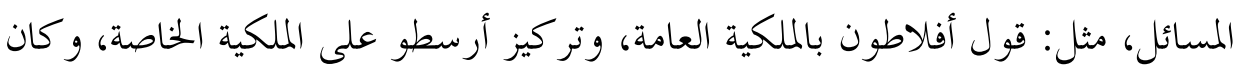

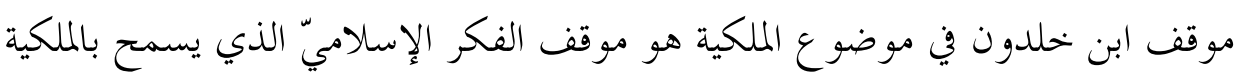

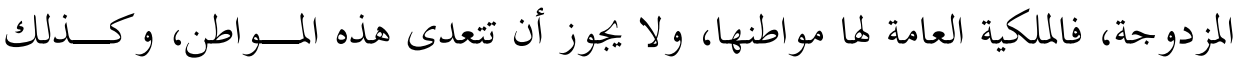

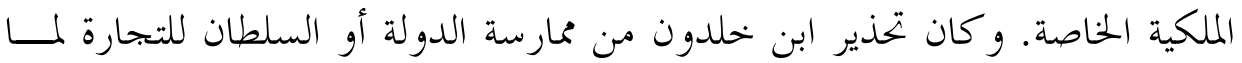

$$
\text { يترتب على ذلك من تراجع وخراب. }
$$

كما أنه خالف أفلاطون في كراهيته للنقود الذهبية، إذ إنّه عدّ الذهب و الفضة هما

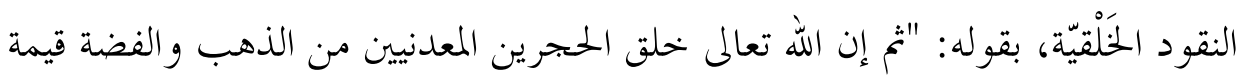

$$
\begin{aligned}
& \text { المرجع السابق، ص 09 ع ـ. }
\end{aligned}
$$

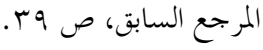




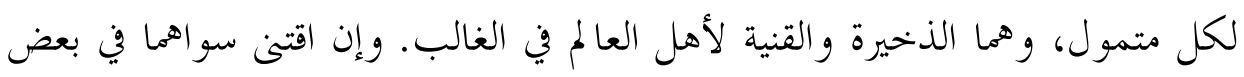

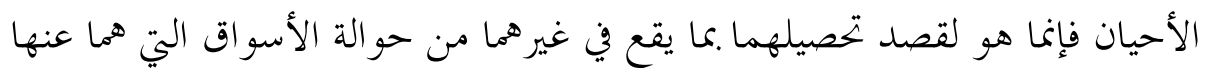
(9)" معزل، فهما أصل المكاسب و القنية والذخيرة.

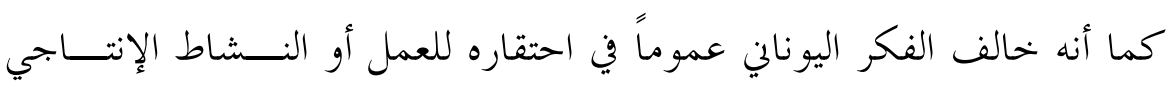

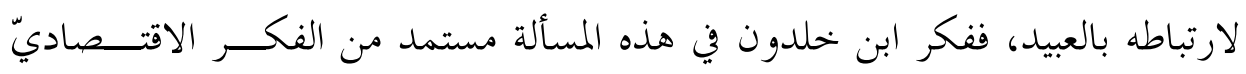

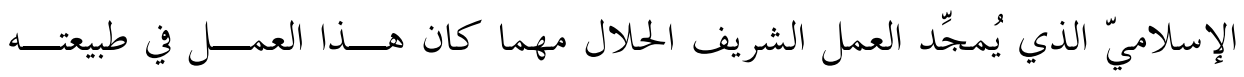

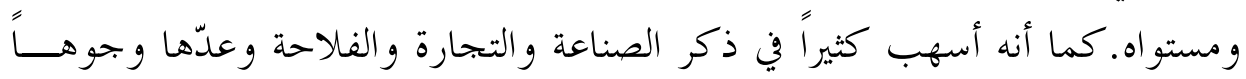

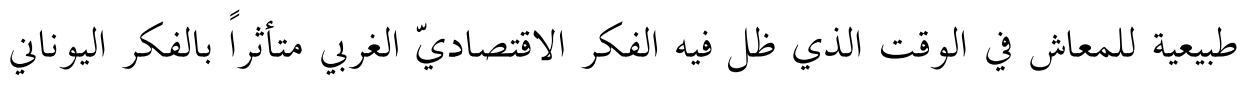

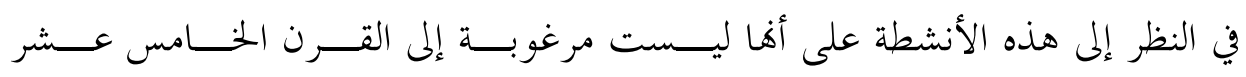
الميلادي. (1.)

ثالثاً: ابن خلدون والفكر الاقتصاديّ الإسلاميّ:

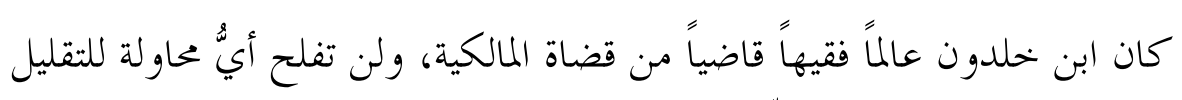

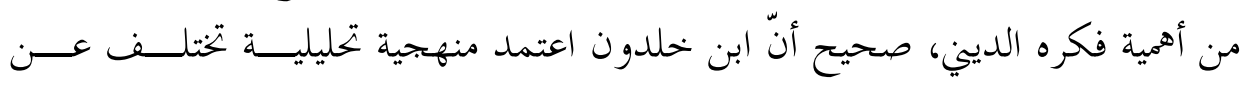

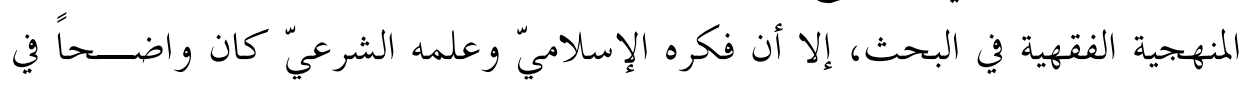

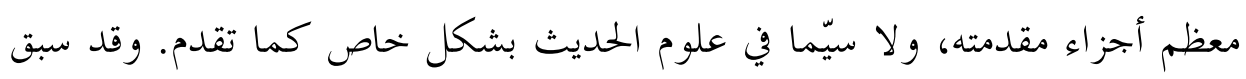

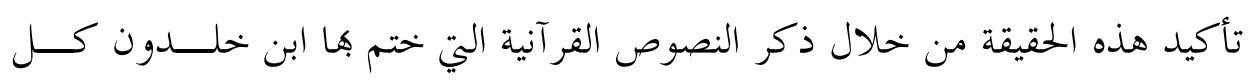

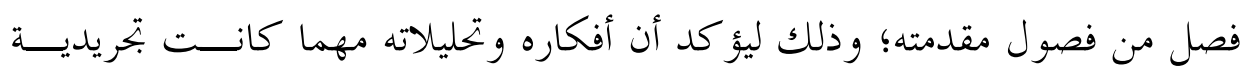

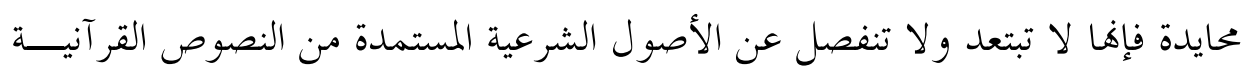

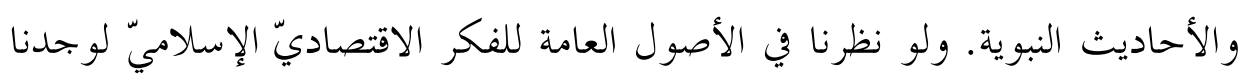
ابن خلدون يؤ كد هذه الأصول ويبين أفكاره على هداهاها.

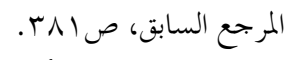

(• (1) الشكعة، مصطفى. الأسس الإسلامية في فكر ابن خلدون، القاهرة: الـــار المـصرية اللبنانيسة، 91919 1، 


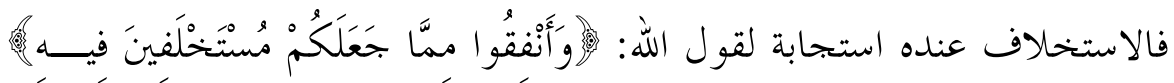

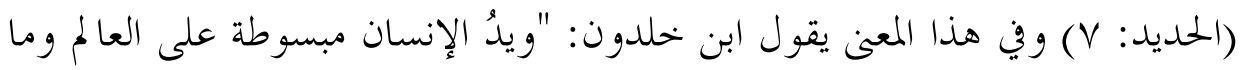

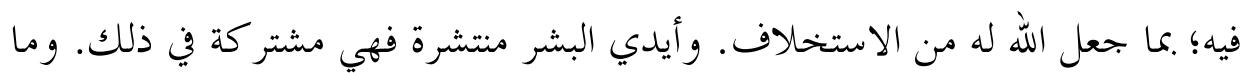

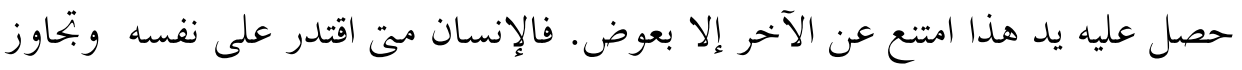

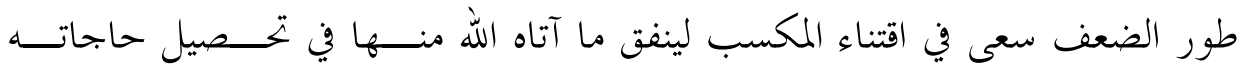

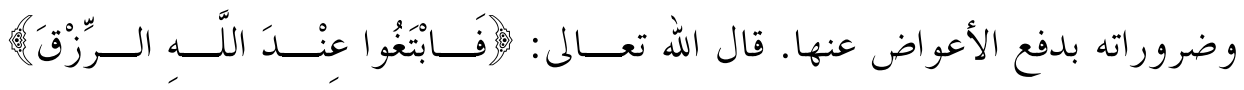

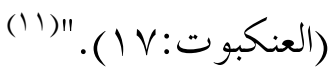

و الإسلام يهدف إلى عدالة التوزيع وتقليل حدة التفاوت؛ لكي لا يو جد في البحتمع

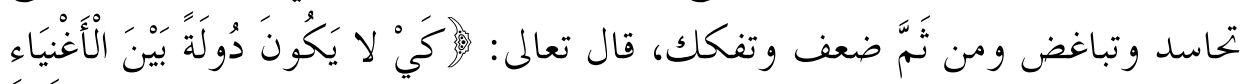

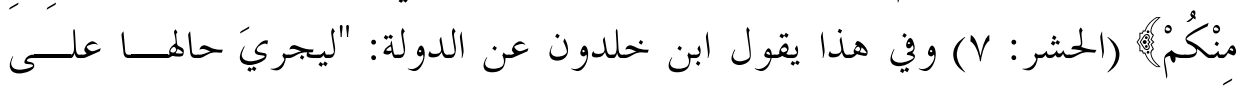

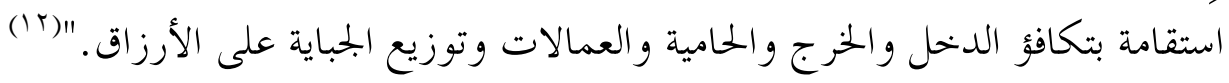

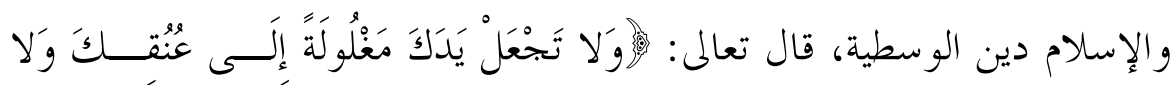

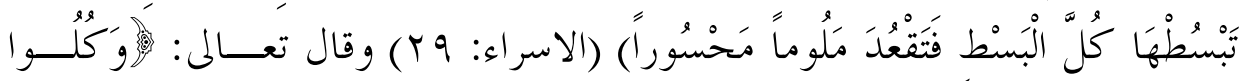

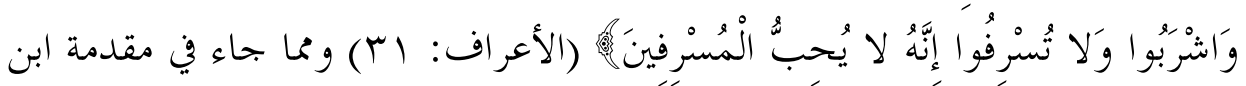

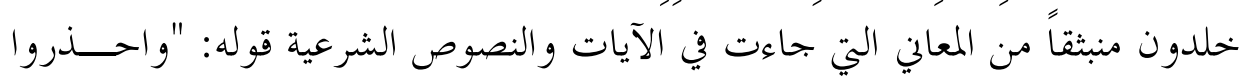

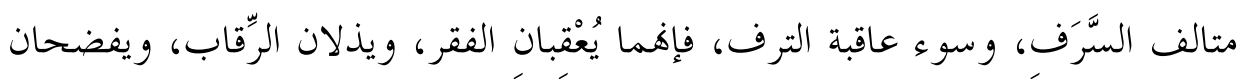

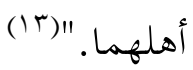

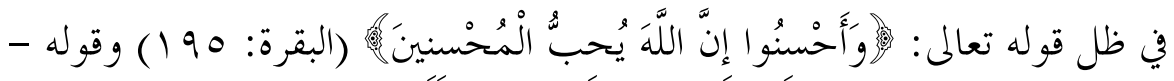

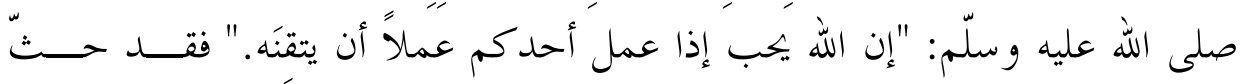

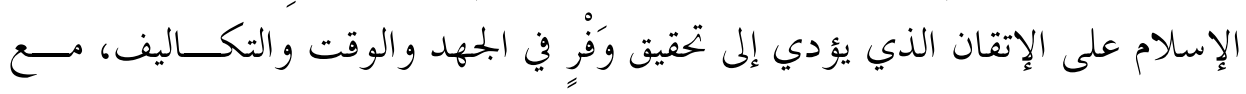

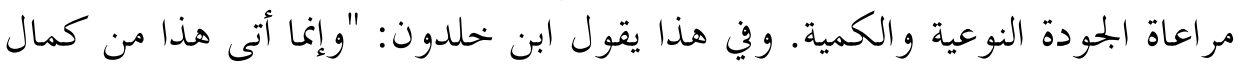

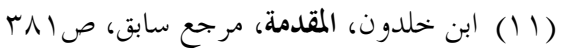
ا 
الصنائع ووفورها بكثرة العمران وانفساح الأعمال. وقد كان الخط العربي بالغاً مبالغه

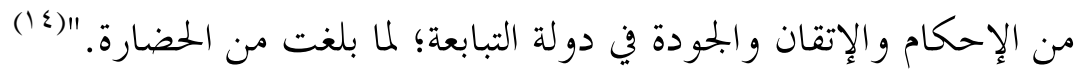
وفي الإطار نفسه، يمكن الثركيز على بعض النماذج التي أوردها ابن خلـــــون في

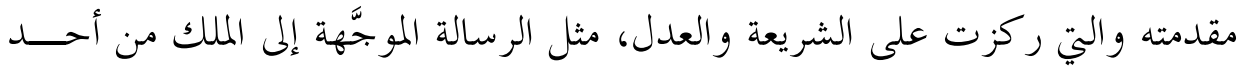

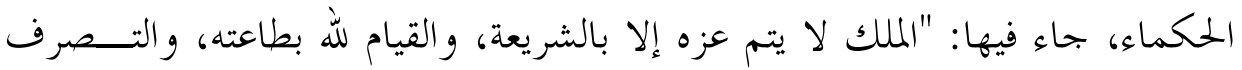

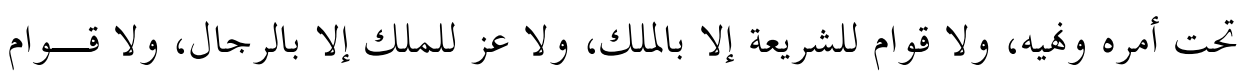

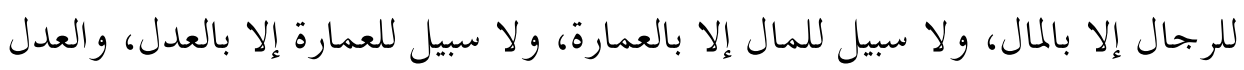

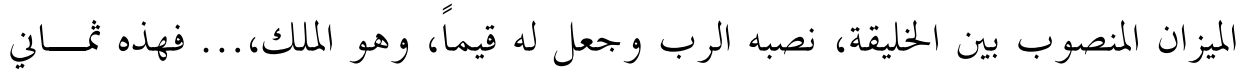

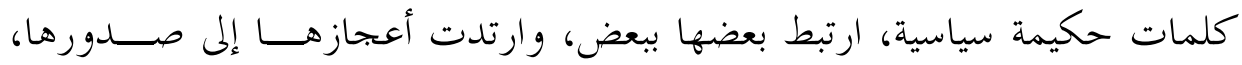

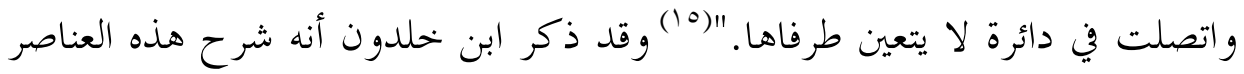

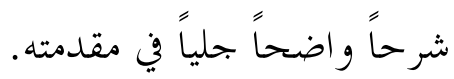

وقد عبر د. شابر اعن هذا النموذج الذي أورده ابن خلدون في صورة علاقة دالية

$$
\text { ( ) }
$$

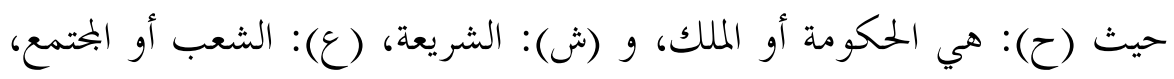

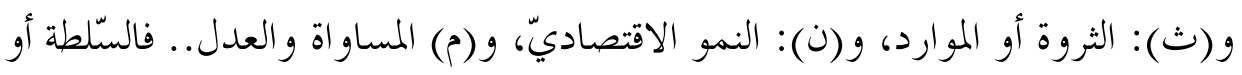

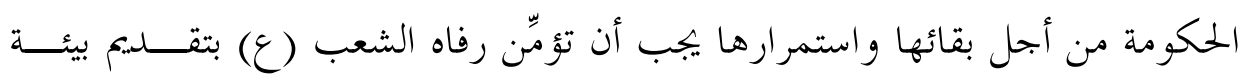

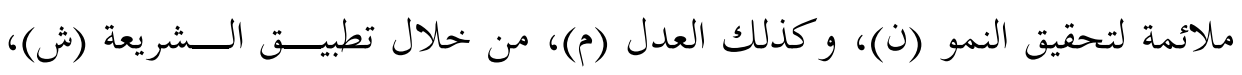

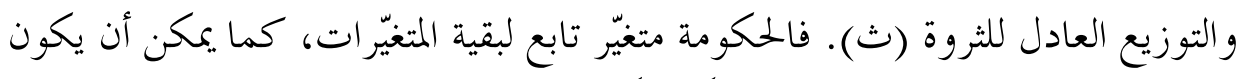

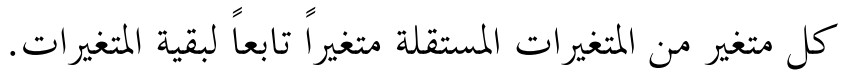

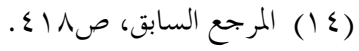

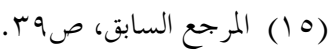

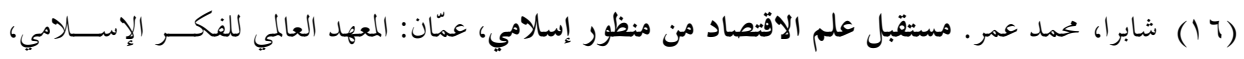


وقد عبر شابرا عن المتغيرات السابقة برسم على شكل بنمة خماسية على رأس كل

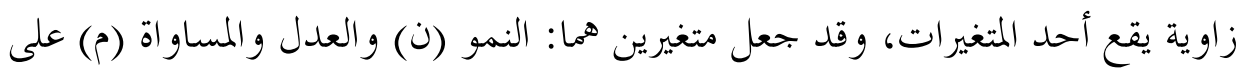

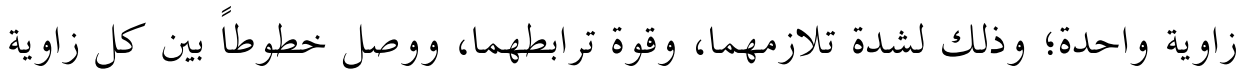

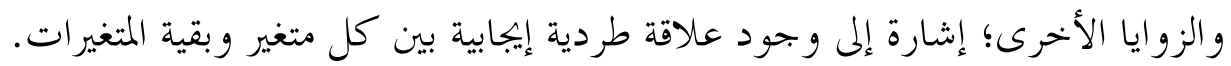
إن هذا النموذج الخلدو ين يعد بحثاً تحليلياً متقدماً سابقاً لعصره، و بالرغم من مرور

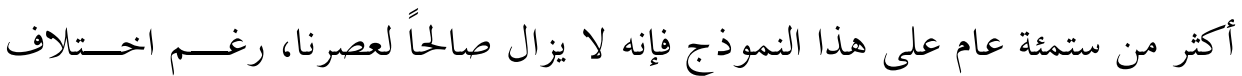

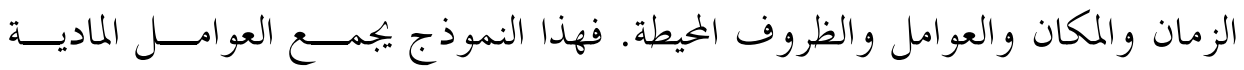

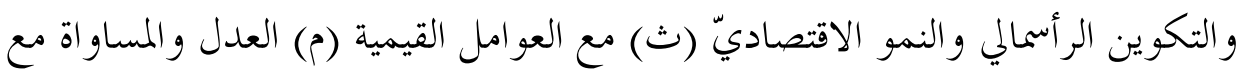

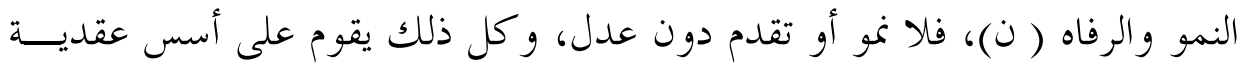

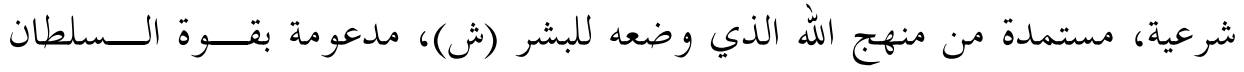

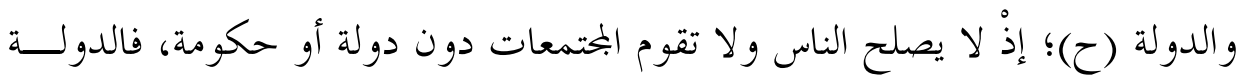

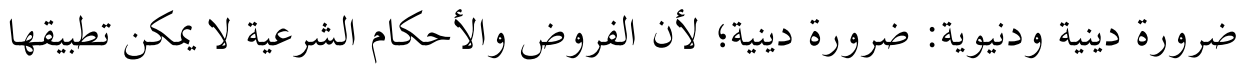

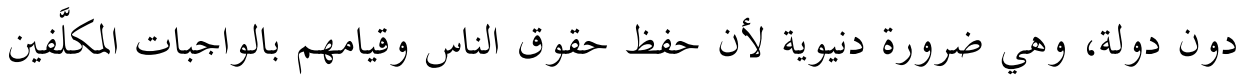

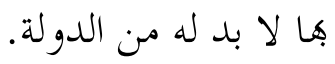

\section{رابعاً: الفكر الاقتصاديّ الخلدووني وتأثيره على الفكر الغربي:}

تتفق المصادر التاريخية والاقتصاديّة على أن الفترة الممتدة مـــن القـــــن الخـــامس

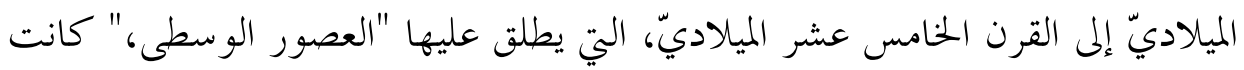
فترة انخطاط وتخلف في أوروبا؛ ما جعل الكثير من المؤرخيــن يطلق على تلك الكئ الفترة "عصر الظلمات."

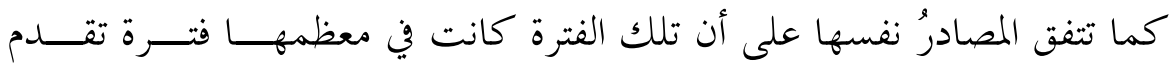

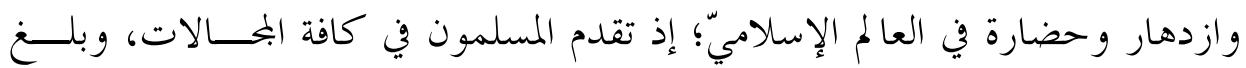

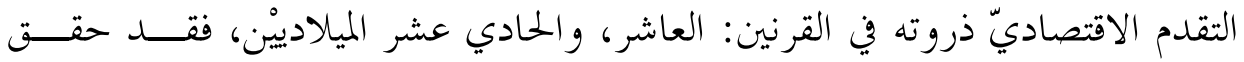




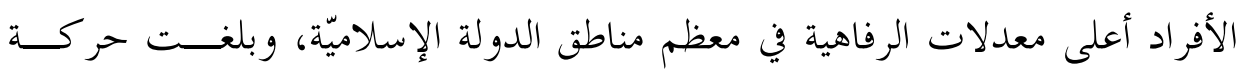

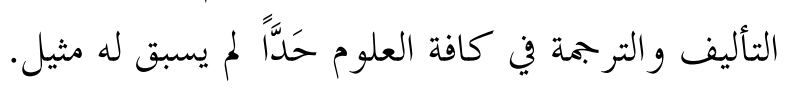

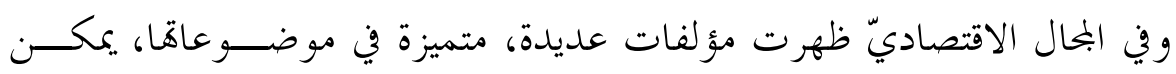

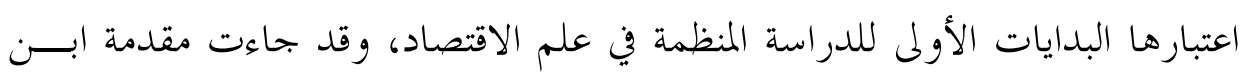

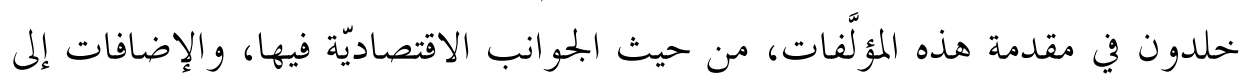

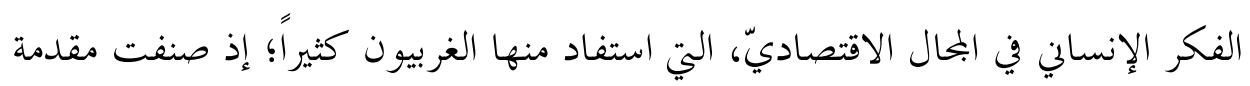

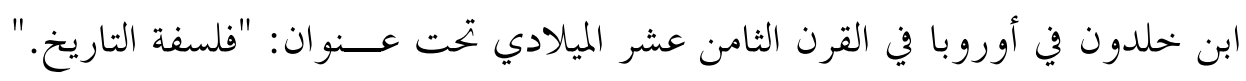

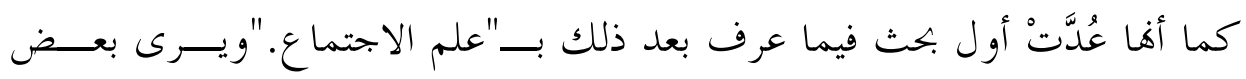

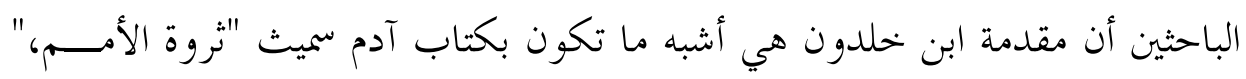

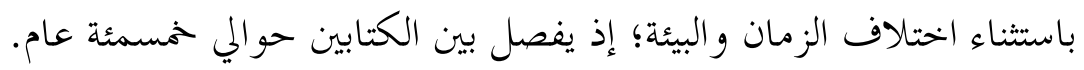

وقد تميزت أفكار ابن خلدون في البحال الاقتصاديّ بالحياد العلمي أو الموضوعية؛

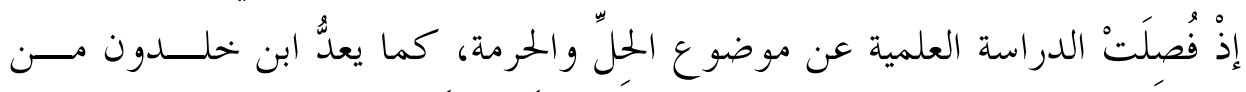

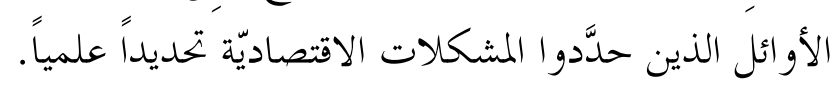

وقد اتبع ابن خلدون ما يسمى في العلوم الاقتصاديّة بالطريقة الديناميكية، الــتي

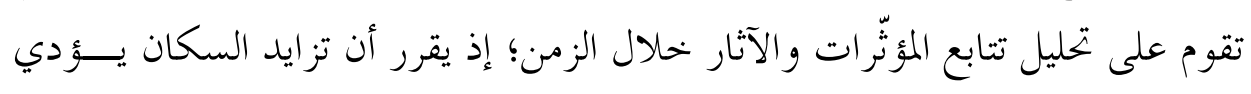

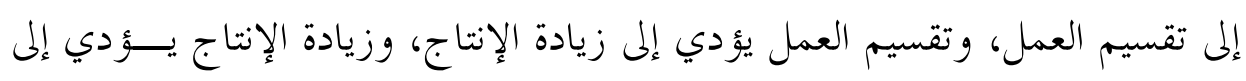

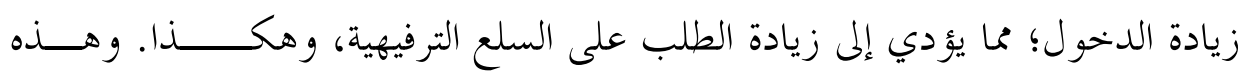

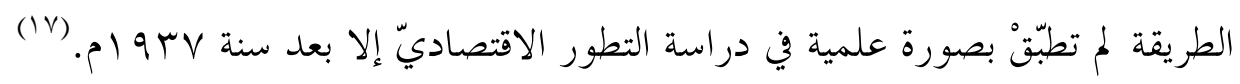
ومن أجل المزيد من التمحيص في الفكر الاقتصاديّ عند ابن خلدون، يمكن إبراز

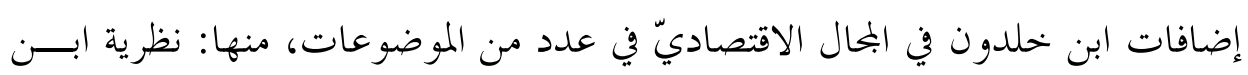

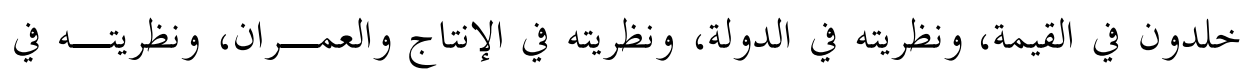
الإنفاق و الضرائب، ونظريته في التجارة. ونطريته في النول، ونظر 


\section{1 ا ـ نظرية ابن خلدون في القيمة:}

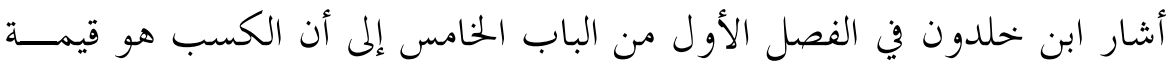

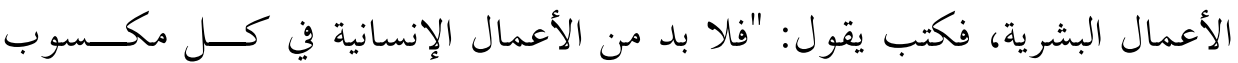

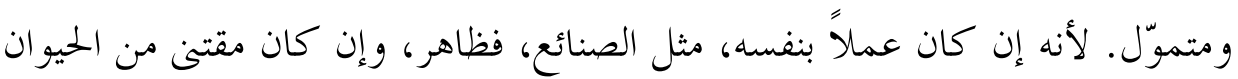

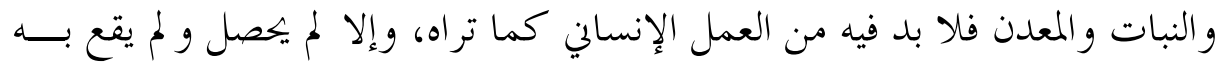

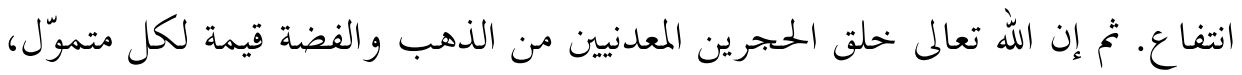

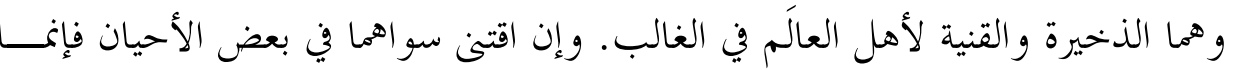

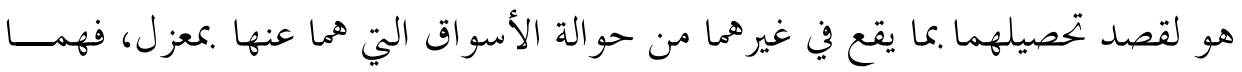

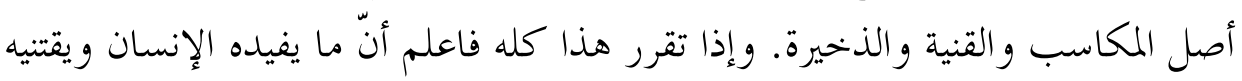

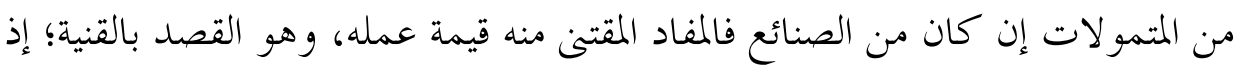

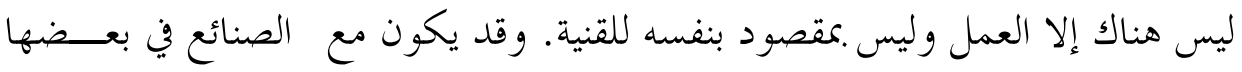

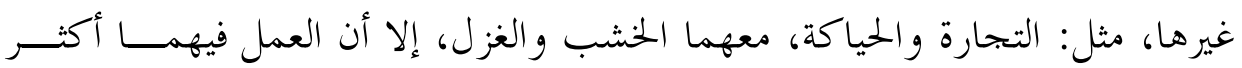

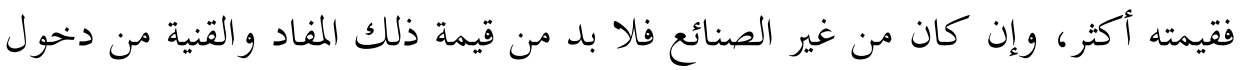

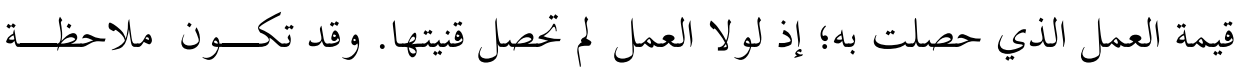

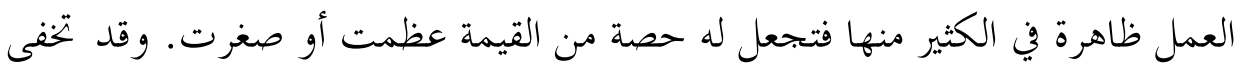

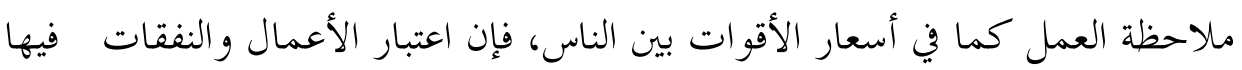

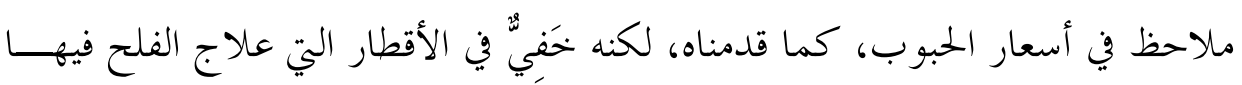

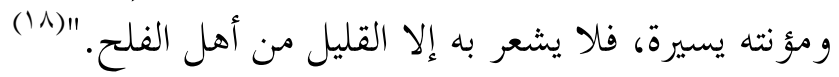
ففي النص السابق أشار ابن خلدون إلى وظائف النقد التي يتفق عليها الاقتصادي”

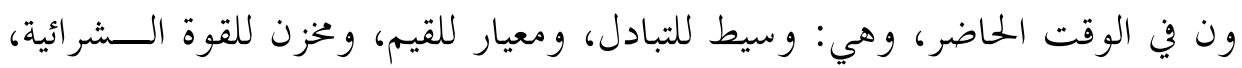
وو سيلة للمدفوعات المؤجلة.

كما أشار إلى نظرية النفقة، ونظرية المنفعة التي حار المفكرون والباحثون الغربيون

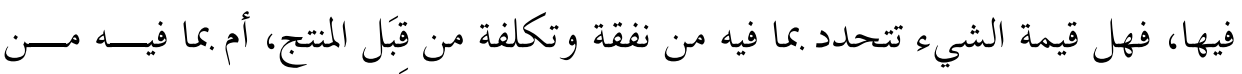


منفعة وفائدة للمستهلك؟ وقد حاول آدم سميث ترجيح نظرية النفقة والتكلفة بالقول:

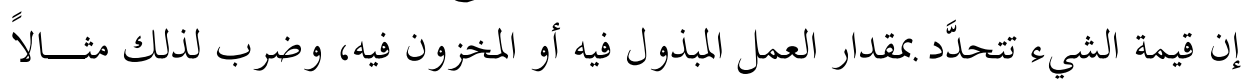

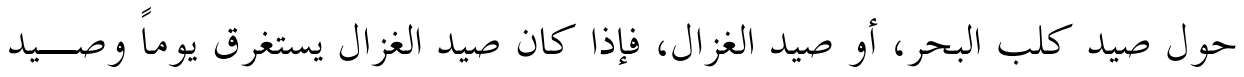

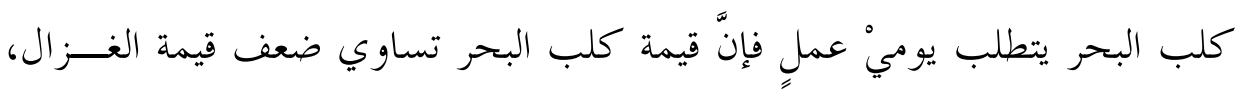

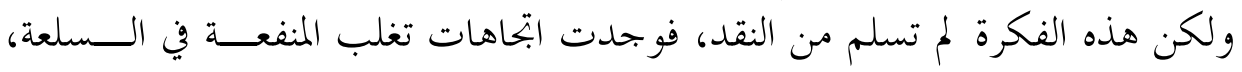
ومدى حاجة المستهلك إليها.

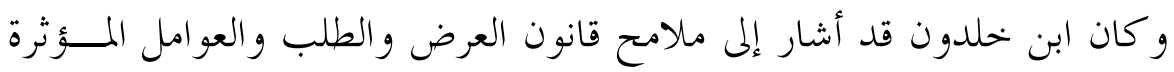

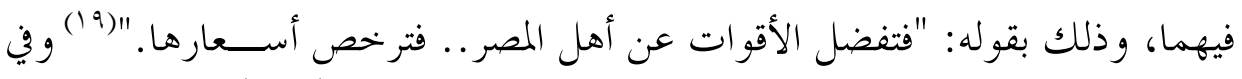

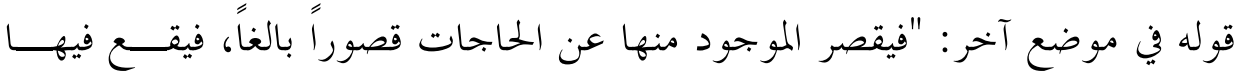

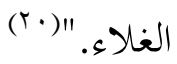

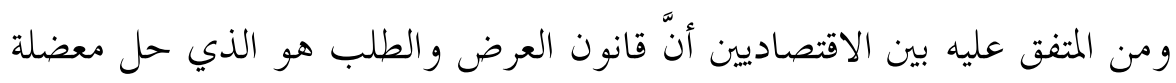

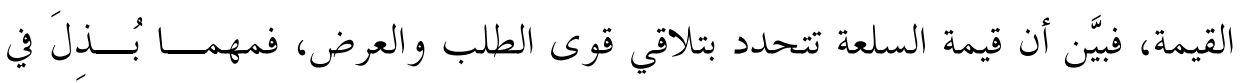

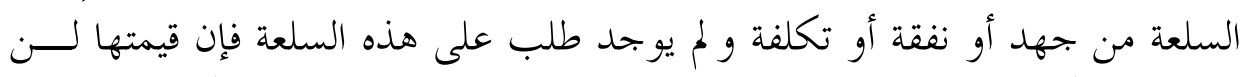

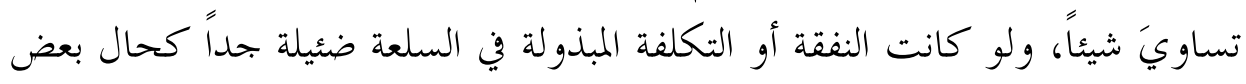

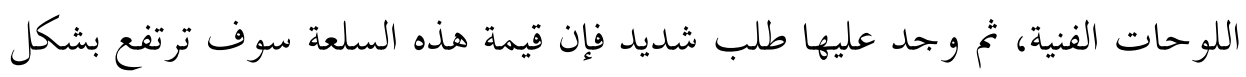

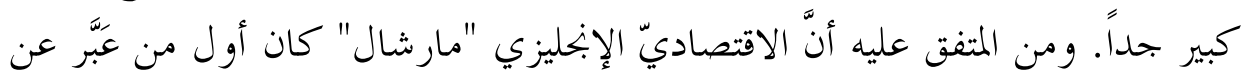

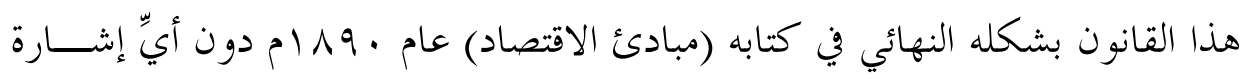

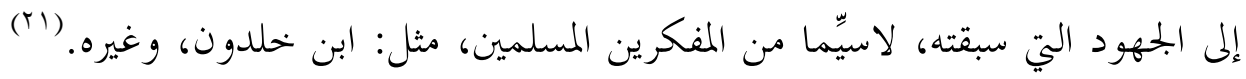

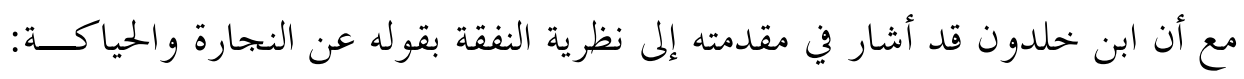

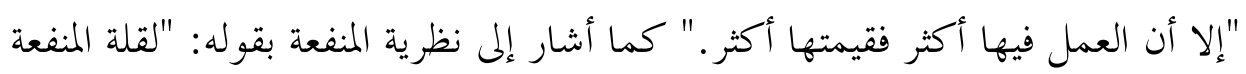

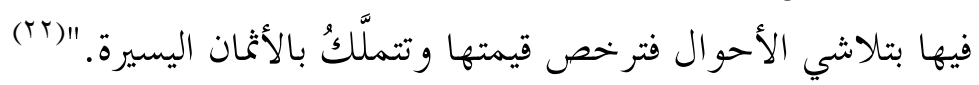

$$
\begin{aligned}
& \text { (9) (19) المرجع السابق، صrابr. }
\end{aligned}
$$

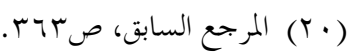

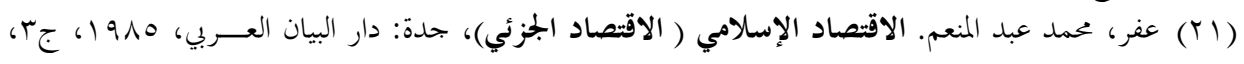


ومما تقدم بند أن ابن خلدون قد سبق كثيراً من المفكرين الأوروبيين في تقريسـر

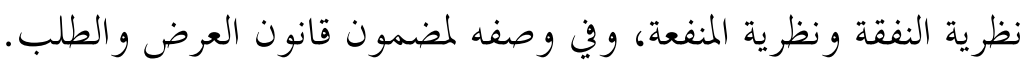
ومن جهة أخرى فقد حلل ابن خلدون ما يسمى في الاقتصاد المعاصر بظــاهرة

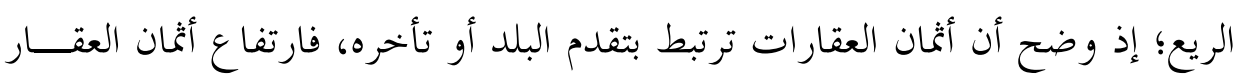

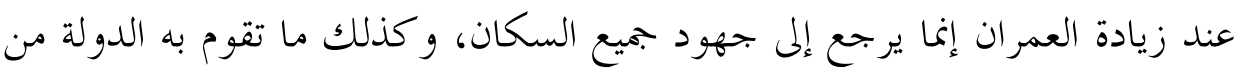

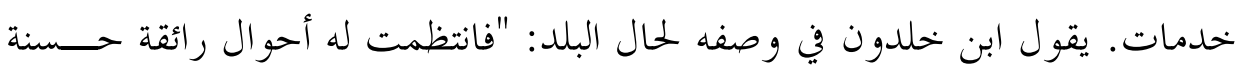

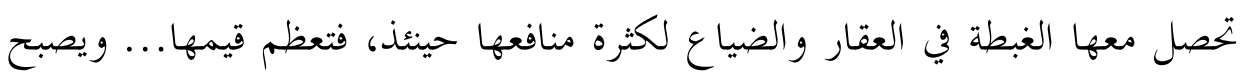

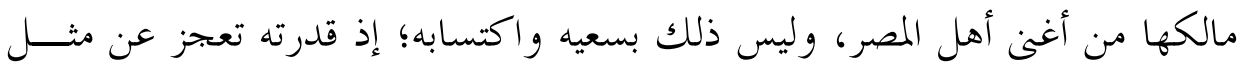

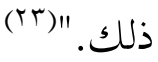

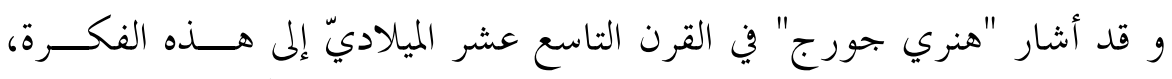

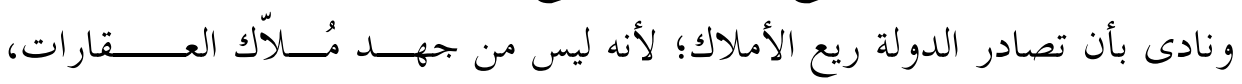

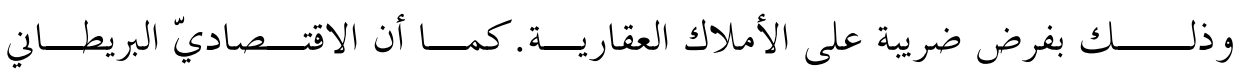

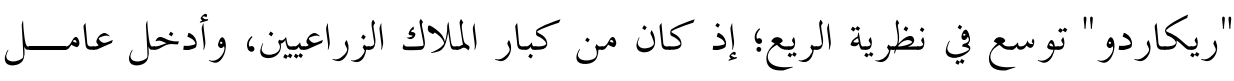

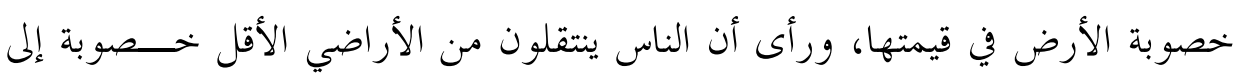

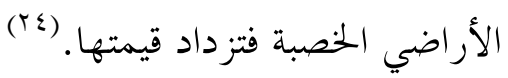

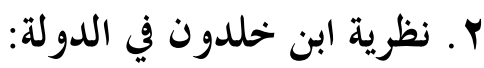

يرى ابن خلدون ضرورة عدم ممارسة الدولة للنشاط الاقتصاديّ بقوله: "التجارة

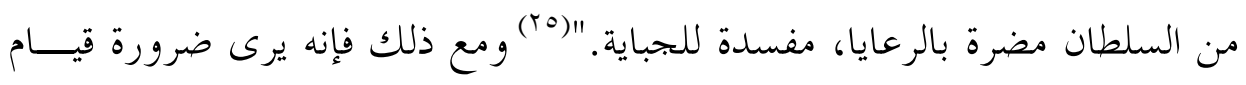

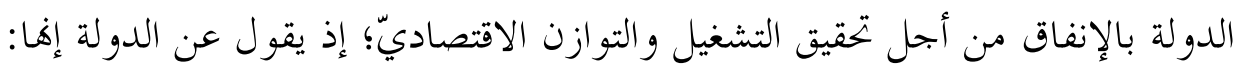

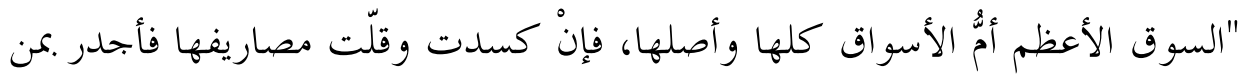

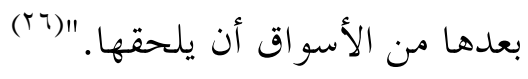

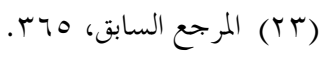

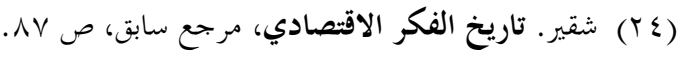

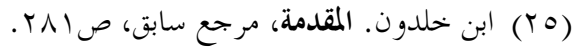

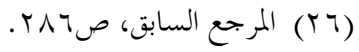


وهذه هي الأفكار نفسها التي تبناها "كينــز"، ودعا إلى تطبيقها في الثلاثينيّـات

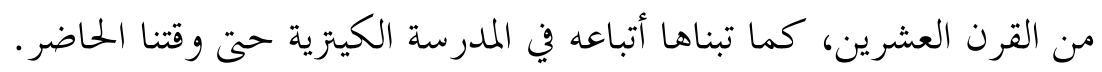

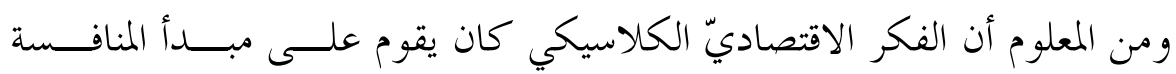

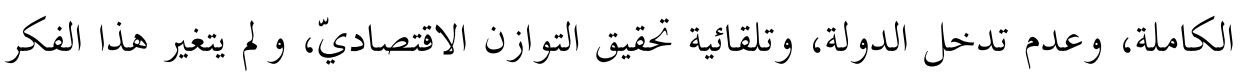

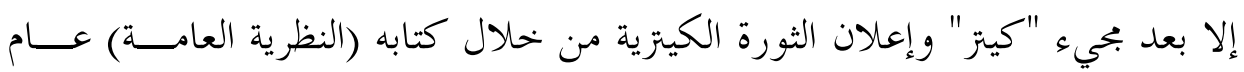

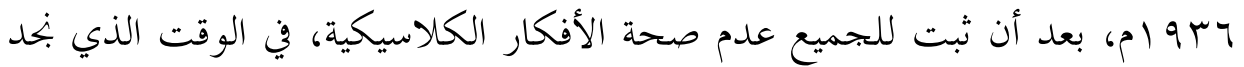

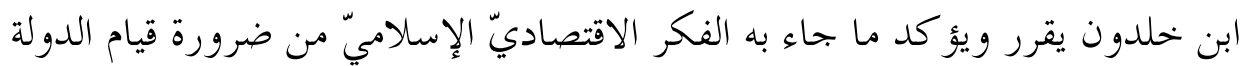

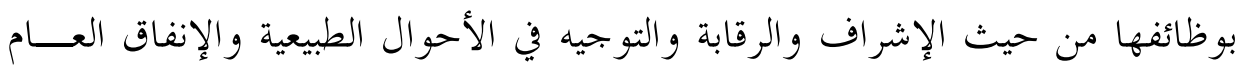

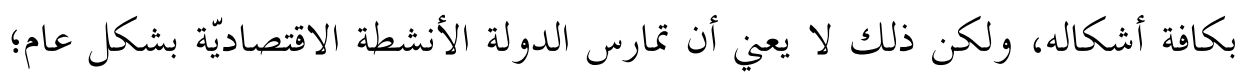

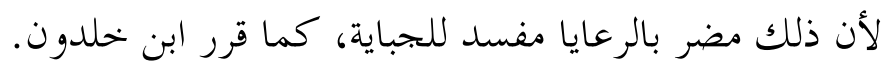

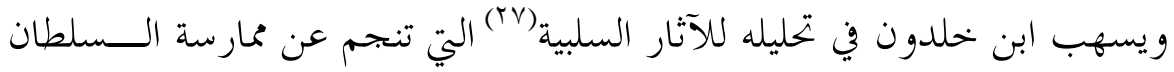

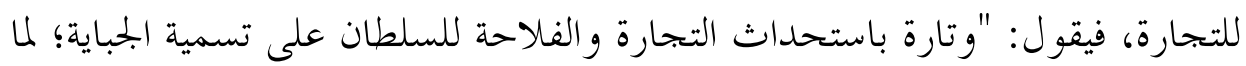

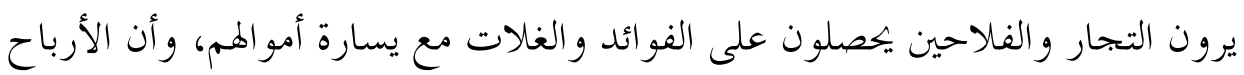

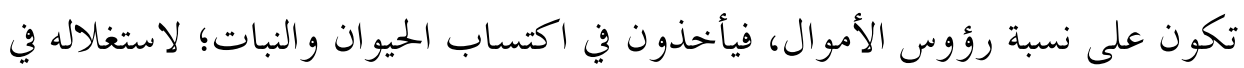

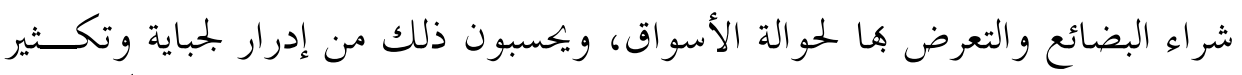

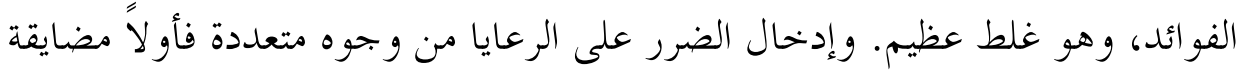

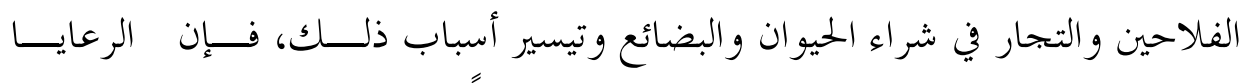

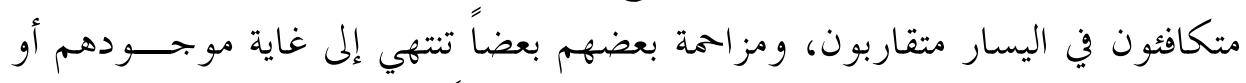

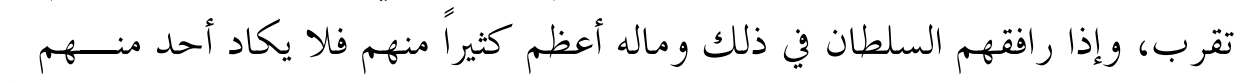

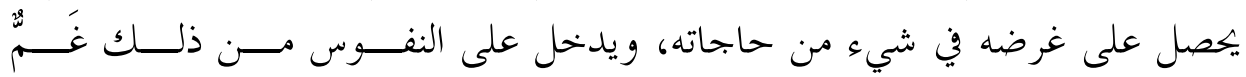
ونكد." (†人)

ومن خلال النص السابق ونصوص أخرى كثيرة يظهر أنّ ابن خلدون كان ينادي

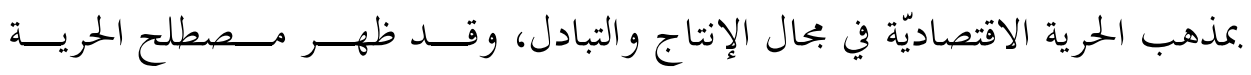


الاقتصاديّة مع مدرسة الطبيعيين في القرن الثامن عشر، مما يعني أن مساهمة ابن خلدون

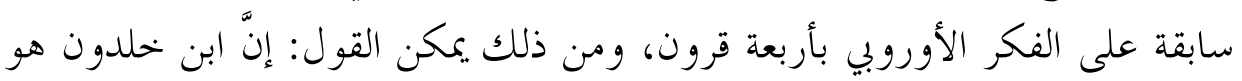

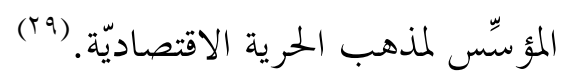

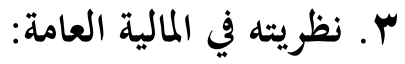

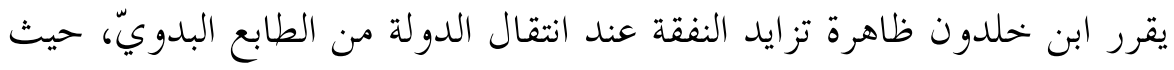

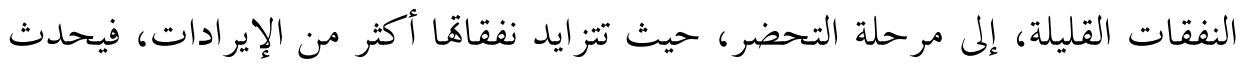

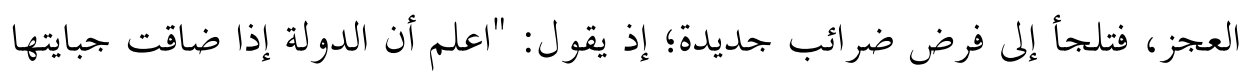

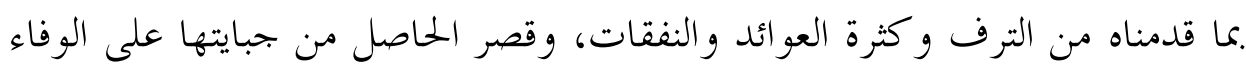

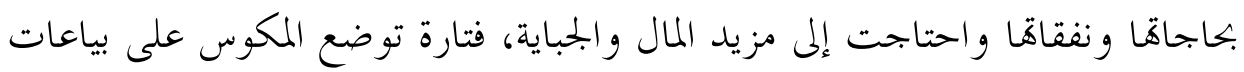

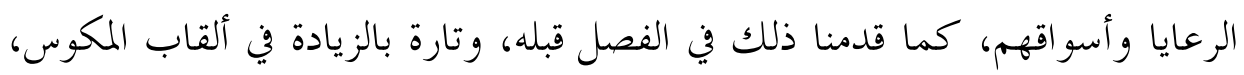

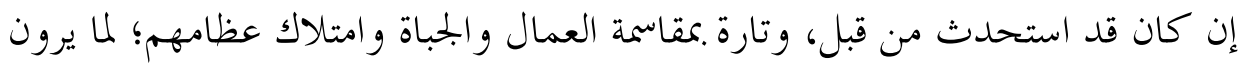

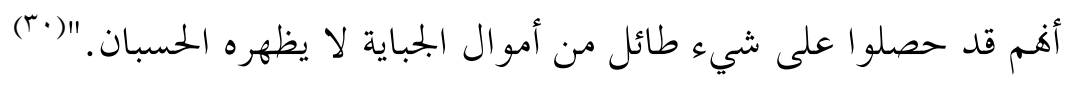
كما رفض فكرة ضغط النفقات؛ لما لذلك من آثار انكماشية؛ إذ يرى ضـــرورة

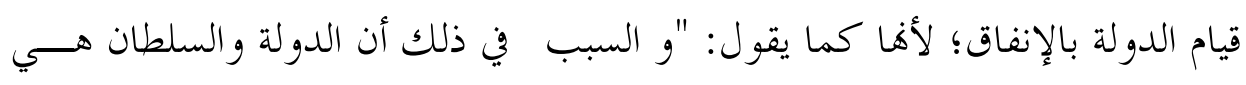

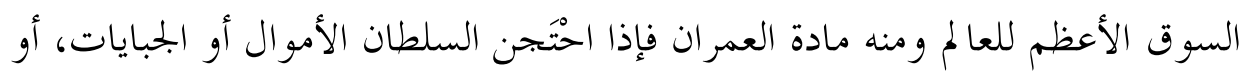
فقدت فلم يصرفها في مصارفها قل حينئ ما بأيدي الحاشية والحامية، وانقطع -أيضاًما كان يصل منهم لحاشيتهم وذويهم وقلت نفقاهم جملة وهم معظم السو اد، ونفقاهم

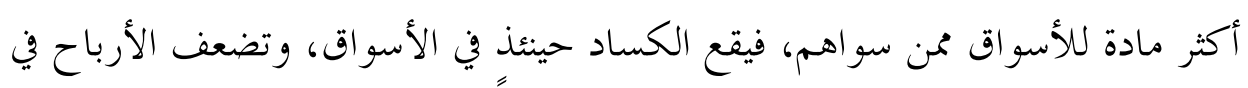

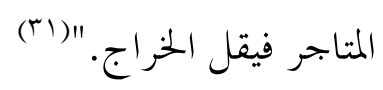

(T9) العوضي، رفعت. تراث المسلمين العلمي في الاقتصاد، القاهرة: مركز صالخ كامـل، جامعـة الأزهــ،

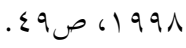

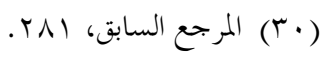

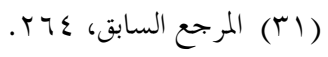


كما أوضح قواعد الجباية التي تتمثل بالمساواة، و الملاءمة، و العدالة، والقدرة على

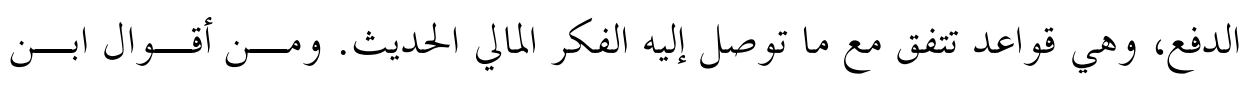

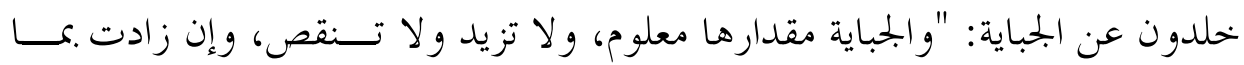

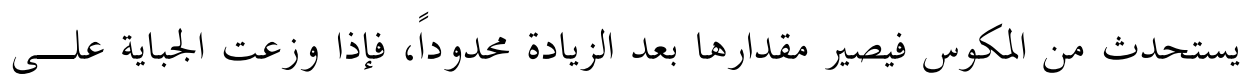

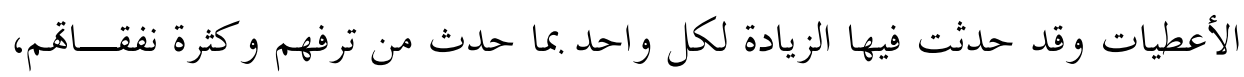
نقص عدد الحامية حينئذ عما كان قبل زيادة الأعطيات، ثم يعظم الترف وتكثر مقادير

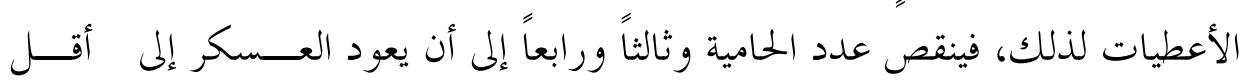
الأعداد فتضعف الحماية لذلك، وتسقط قوة الدولة، ويتجاسر عليها من يجاورها من

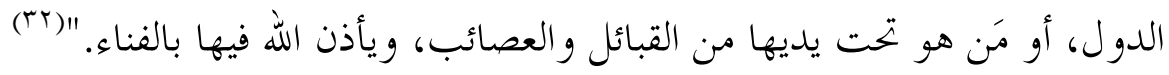
ويتضح من هذا النص أنّ ابن خلدون كان يرى عدم زيادة الضرائب ( المكوس) على الناس؛ لما لذلك من آثار خطيرة على المجتمع؛ إذ تزيد الضرائب من ترف المترفين

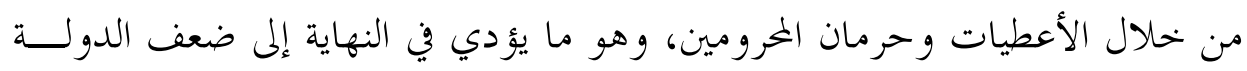
ويأذن الله فيها بالفناء.

وقد أشاد الرئيس الأمريكي (ريغان) بفكر ابن خلدون في بحال تخفيض الضرائب

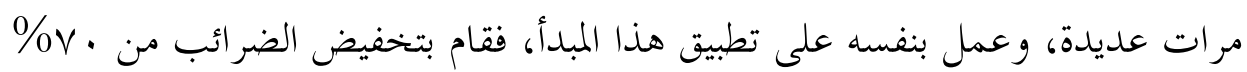

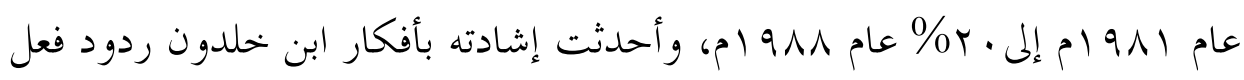

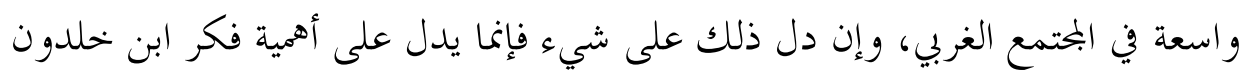

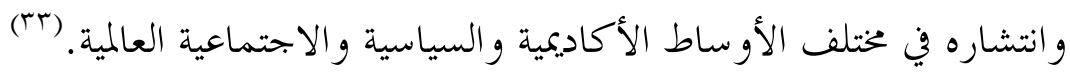

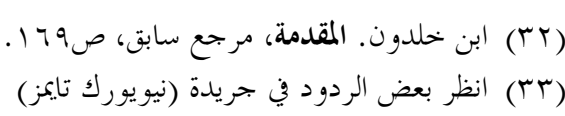
http://query.nytimes.com/gst/fullpage.html?res=9F0CEEDC1230F934A3 $\underline{5750 \mathrm{C} 0 \mathrm{~A} 965958260}$ وانظر أيضاً منحن (لافر) وإشادته بأفكار ابن خلدون حول الضرائب: http://www.heritage.org/Research/Taxes/bg1765.cfm 


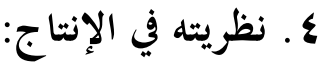

يقرر ابن خلدون أن الفلاحة والصناعة والتجارة من الوجوه الطبيعية للمعــاش،

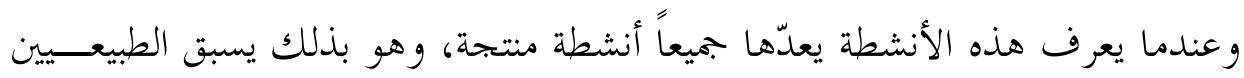

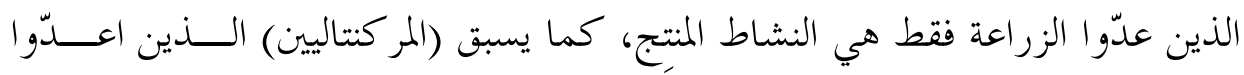

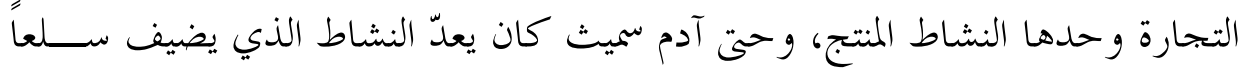

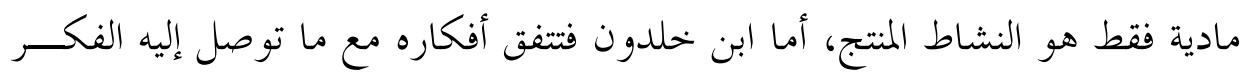
الاقتصاديّ الحديث باعتباره النشاط المنتج هو الذي يضيف سلعاً مادئ مادية أو معنوية.

ومن أقواله في هذا الموضوع: "وأما الفلاحة و الصناعة والتجارة فهي وجوه طبيعية

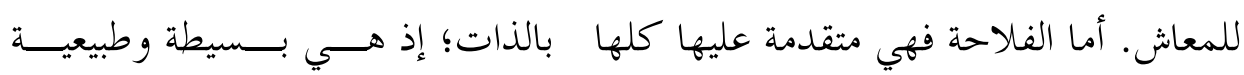

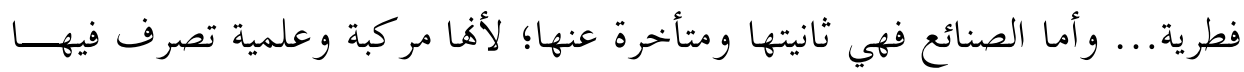

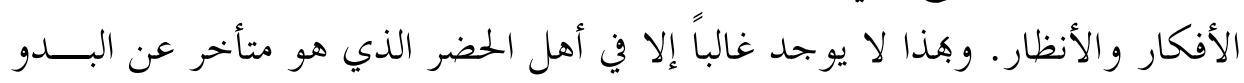

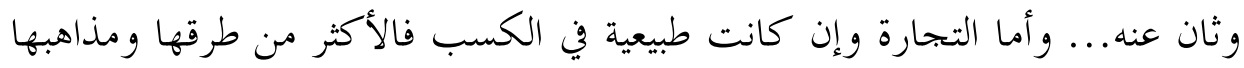

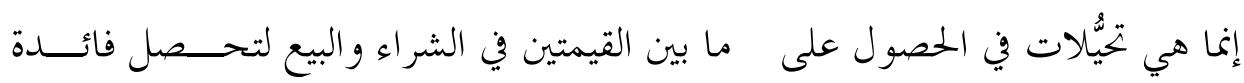

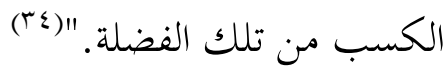

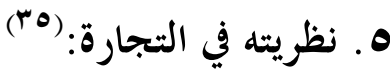

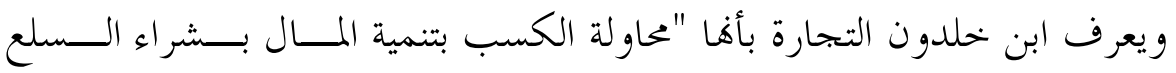

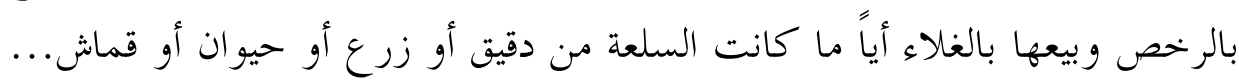

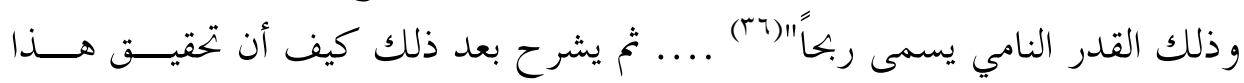

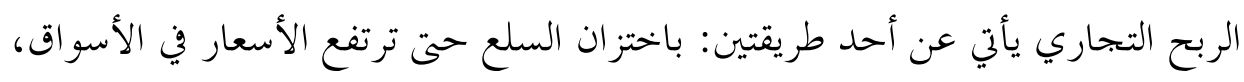
أو بنقل السلع من بلد ترخص فيه أسعارها إلى بلد آخر ترتفع فيه.

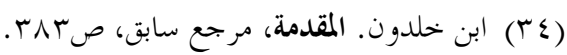

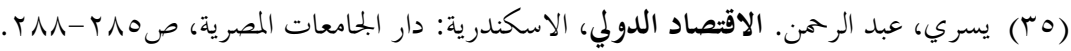

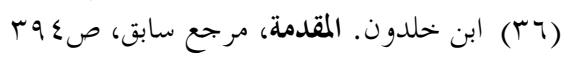


ومن هذا الطريق الثاني يقدم ابن خلدون تحليله للتجارة الخارجية، فنجد أنه يتعمق

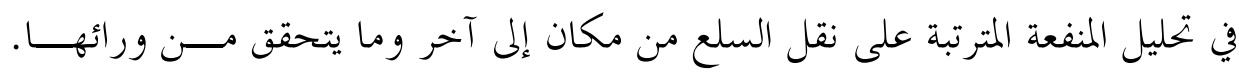

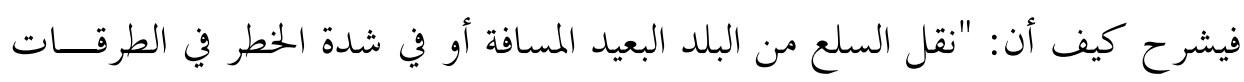

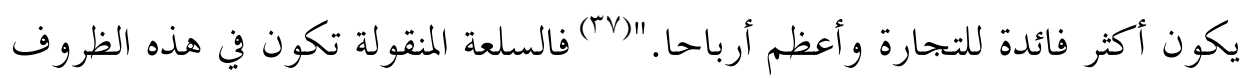

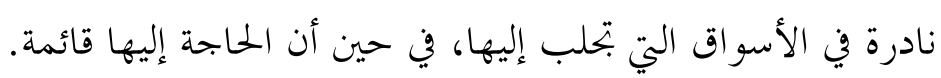

و يعتمد ابن خلدون على الفكرة السابقة نفسها ليؤكد أن التجارة الخارجية أكثر

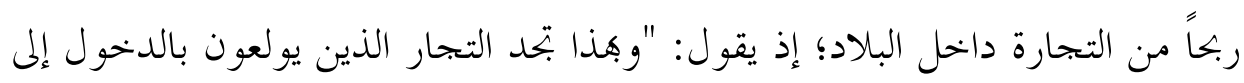

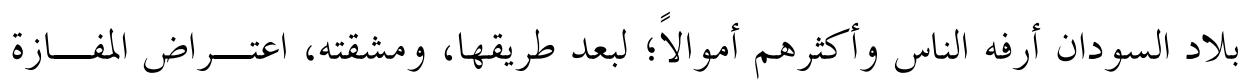

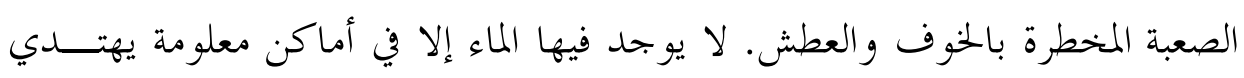

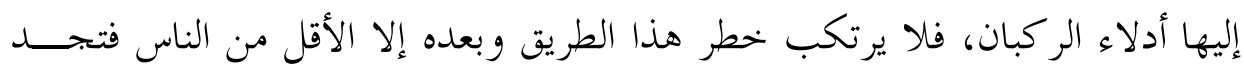

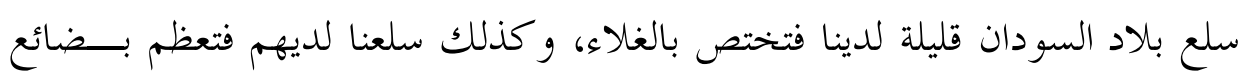

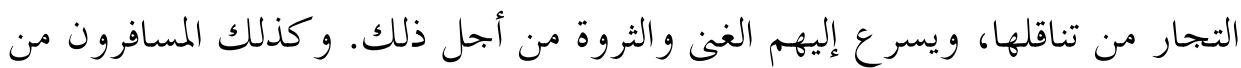

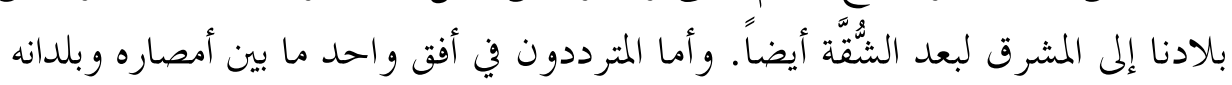

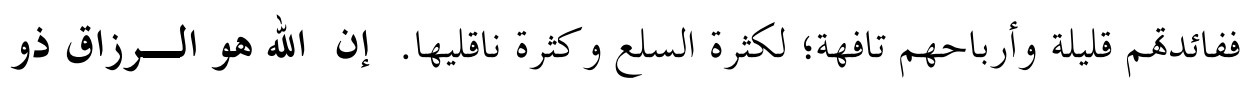

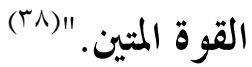

\section{ج.}

تأثر (ريكاردو) بفكرة تقسيم العمل عند آدم سميث، وما ينجم عنها من: زيــادة

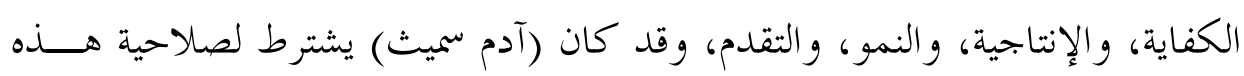

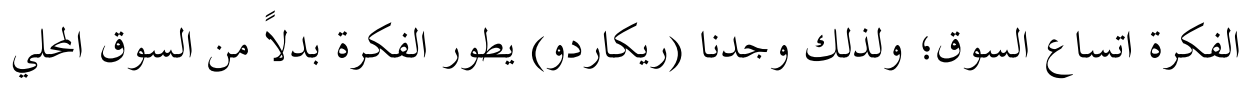

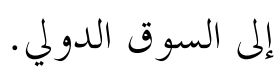


و بالرجوع إلى فكر ابن خلدون بجده يقرر أن فو ائد تقسيم العمل تزداد كلما كبر

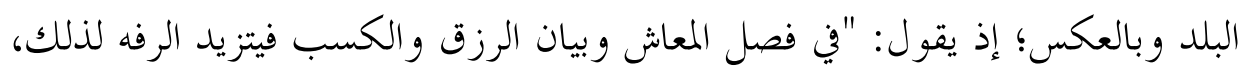

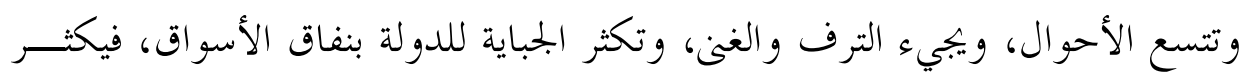

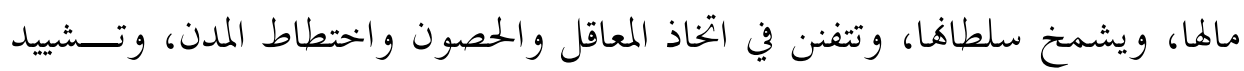

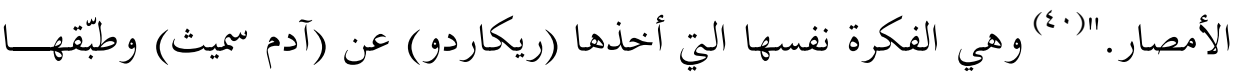
على التجارة الدولية.

الحخاتمة:

إن المتأمل في فكر ابن خلدون من خلال مقدمته فقط يجد بحراً من العلوم لا يكاد

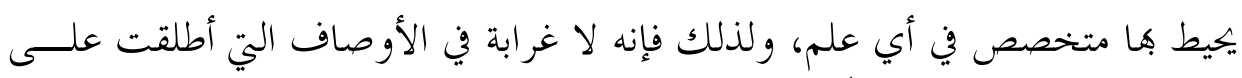

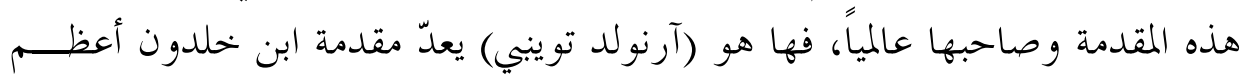

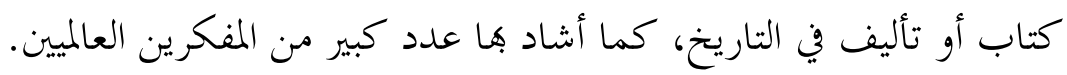

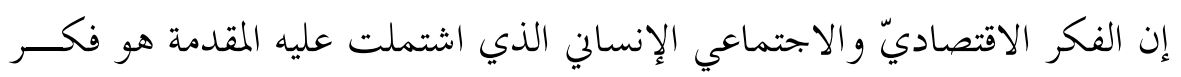

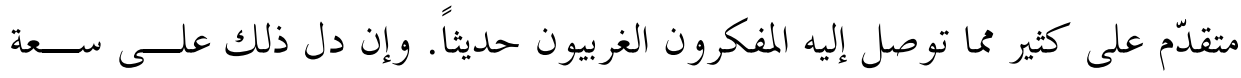

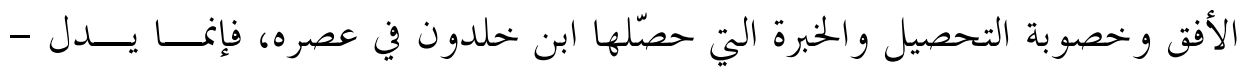

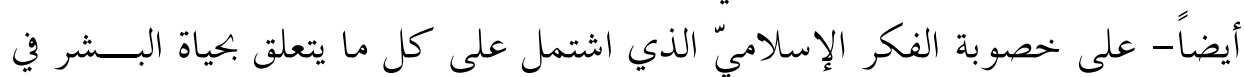
كافة البحالات.

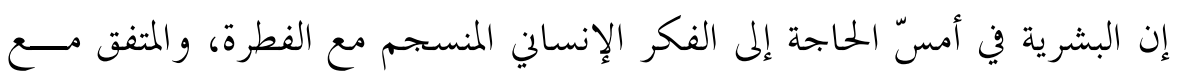

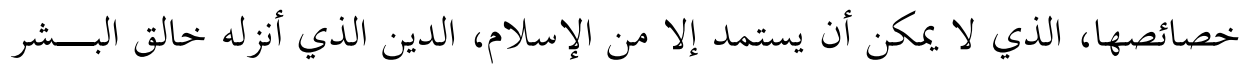

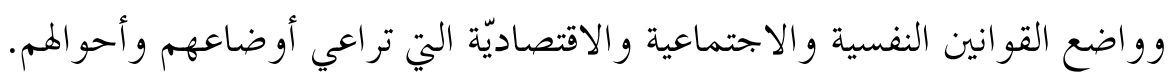

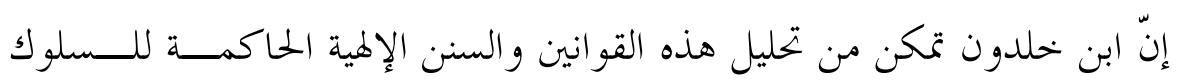

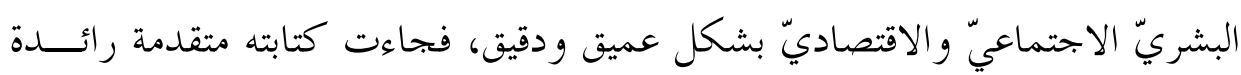

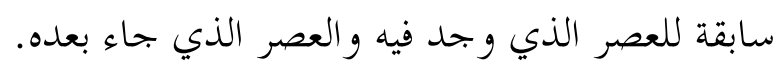


ويمكن تلخيص أبرز الأفكار التي وردت في هذا البحث بما يأتي:

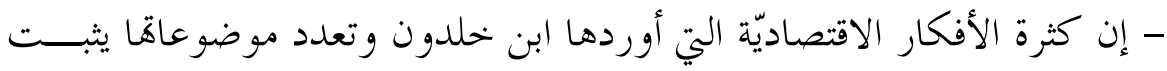

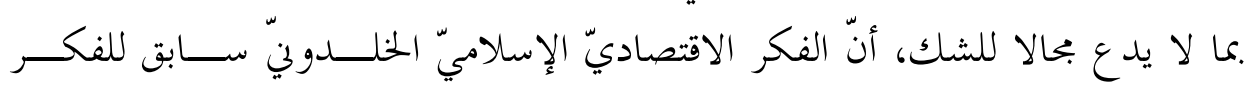

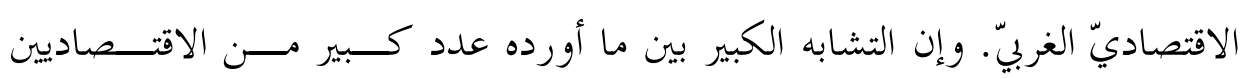

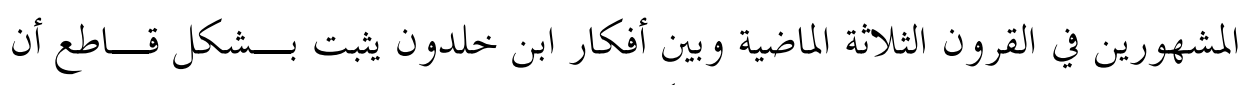

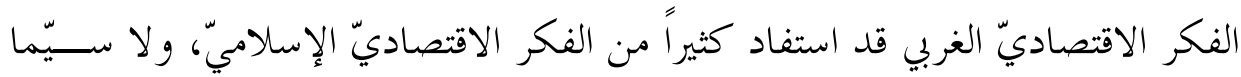
أفكار ابن خلدون وغيره من علماء المسلمين.

- و ولم ينكر ابن خلدون اعتماده على الفكر اليوناني والروماني ودراسات علماء

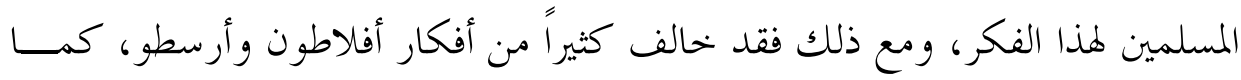

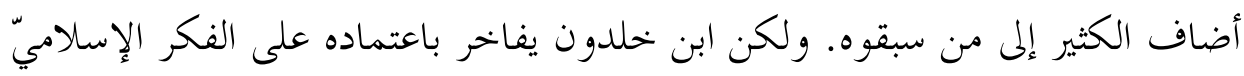

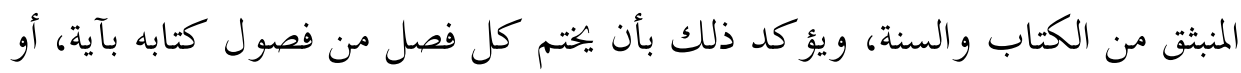
جزء من آية من القرآن الكريم. - إن الأصول التي يقوم عليها الفكر الاقتصاديّ الإسلاميّ هي الأصول نفـسها

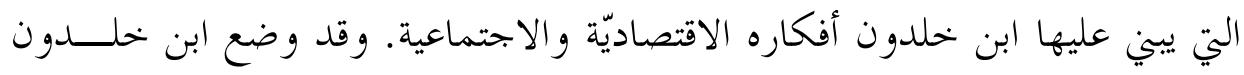

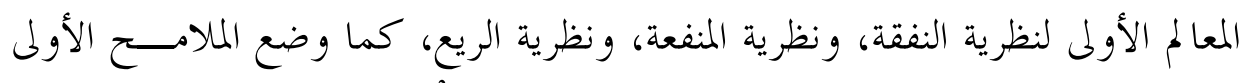

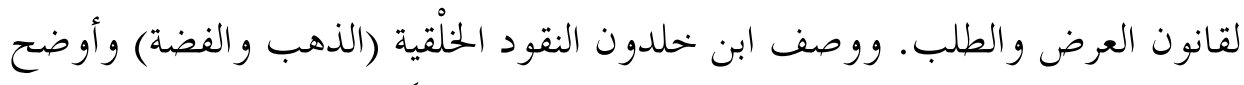

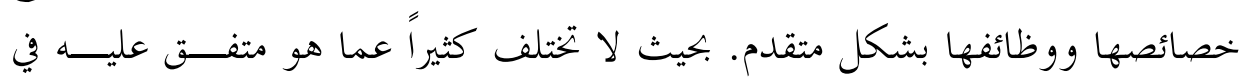
النظريات النقدية الحديثة.

- وضع ابن خلدون قو اعد المالية العامة مثثلة في: المساواة، والملاءمة، و العدالــة،

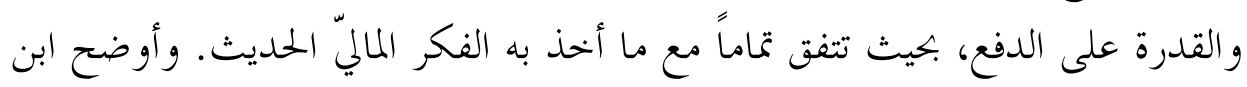

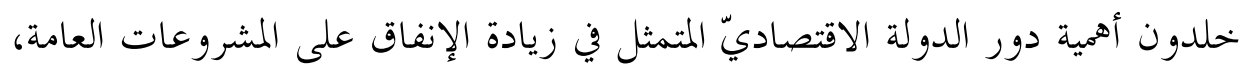

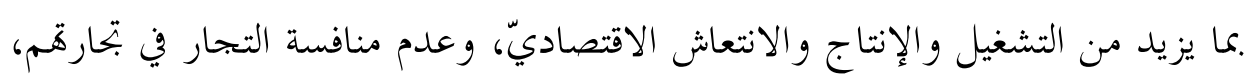
وعدم إرهاق الناس بزيادة الضرائب. 
- أشاد الرئيس الأمريكي (ريغان) بأفكار ابن خلدون في بحال تخفيض الضرائب،

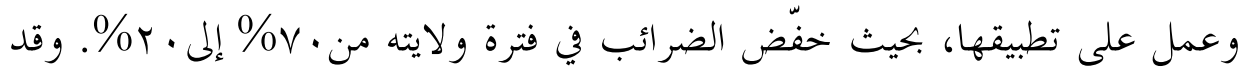

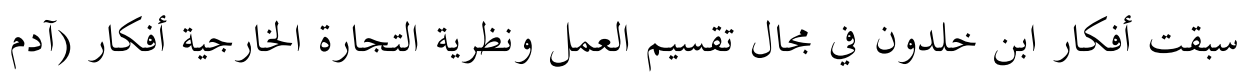
سميث) و و(ريكاردو) وغيرهم من الاقتصاديين المشهورين. - أسهب ابن خلدون كثيراً في ذكر الصناعة والتجارة و الفلاحة وعدّهما وجوهاً

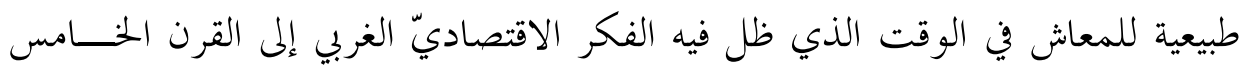

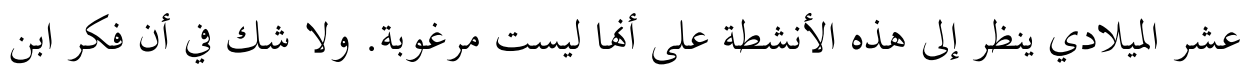

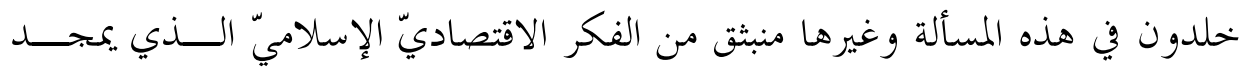

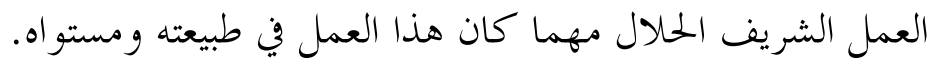

